Portland State University

PDXScholar

1981

\title{
Variation in branch growth characteristics of Pinus contorta infected with Arceuthobium americanum
}

Lynn Anne Larsen

Portland State University

Follow this and additional works at: https://pdxscholar.library.pdx.edu/open_access_etds

Part of the Biology Commons, and the Plant Biology Commons

Let us know how access to this document benefits you.

\section{Recommended Citation}

Larsen, Lynn Anne, "Variation in branch growth characteristics of Pinus contorta infected with Arceuthobium americanum" (1981). Dissertations and Theses. Paper 3058.

https://doi.org/10.15760/etd.3054

This Thesis is brought to you for free and open access. It has been accepted for inclusion in Dissertations and Theses by an authorized administrator of PDXScholar. Please contact us if we can make this document more accessible: pdxscholar@pdx.edu. 
AN ABSTRACT OF THE THESIS of Lynn Anne Larsen for the Master of Science in Biology presented July 31, 1981.

Title: Variation in Branch Growth Characteristics of Pinus contorta Infected with Arceuthobium americanum.

APPROVED BY MEMBERS OF THE THESIS COMMITTEE:
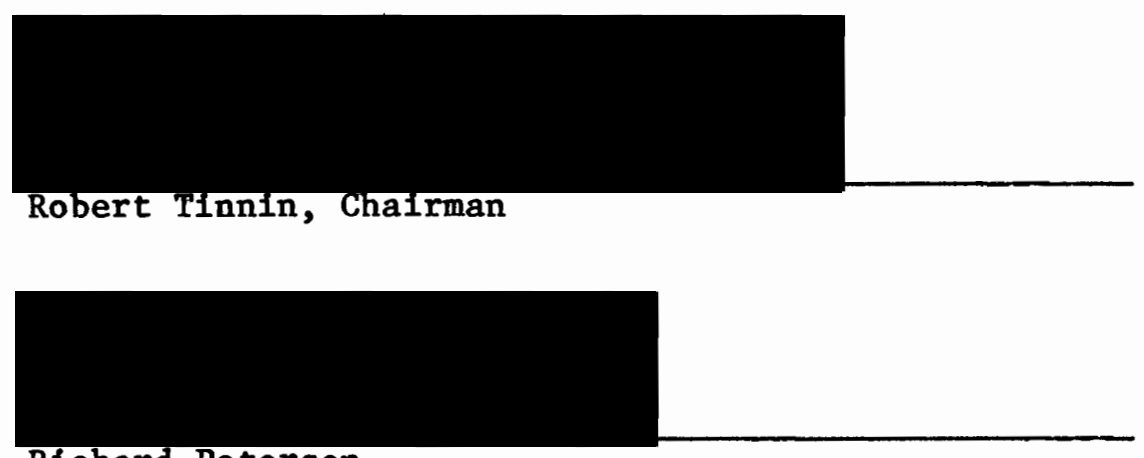

Richard Petersen

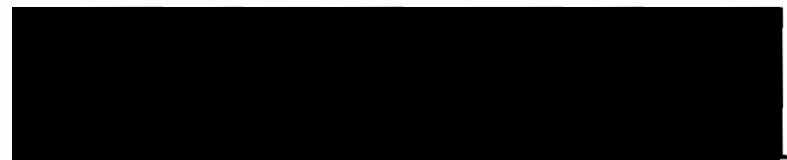

Richard Tocher

Arceuthobium americanum is a flowering plant which parasitizes Pinus contorta (Lodgepole pine). This study examined branch performance of $\underline{P}$. contorta infected to varying degrees with A. $_{\text {americanum. }}$ When uninfected branches were compared to heavily infected branches, a differences in branch growth was observed.

In comparison of uninfected, locally infected, and systemically infected samples from a given dwarf mistletoe rating (DMR), no 
significant differences in branch growth could be determined in most cases. When samples from uninfected, locally infected, or systemically Infected branches were analyzed to determine a difference in branch growth at different DMR, no consistent pattern in branch growth could be determined for the varlables measured.

It is speculated that the system used to assess the level of Infection 18 too refined to accurately account for the observed differences in branch growth. 
VARIATION IN BRANCH GROWTH CHARACTERISTICS OF

PINUS CONTORTA INFECTED WITH

ARCEUTHOBIUM AMERICANUM

BY

LYNN ANNE LARSEN

A thesis submitted in partial fulfillment of the requirements for the degree of

\author{
MASTER OF SCIENCE \\ in \\ BIOLOGY
}

Portland State University

1981 
TO THE OFFICE OF GRADDATE STUDIES AND RESEARCH:

The members of the Committee approve the thesis of

Lynn Anne Larsen presented July 31, 1981.

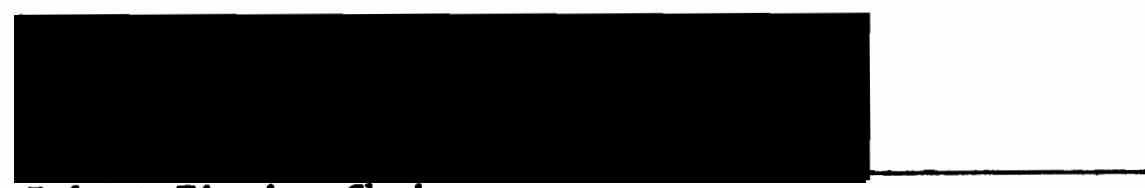

Robert Tinnin, Chairman

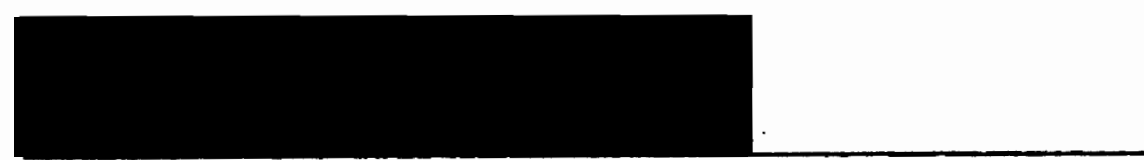

Richard Petersen

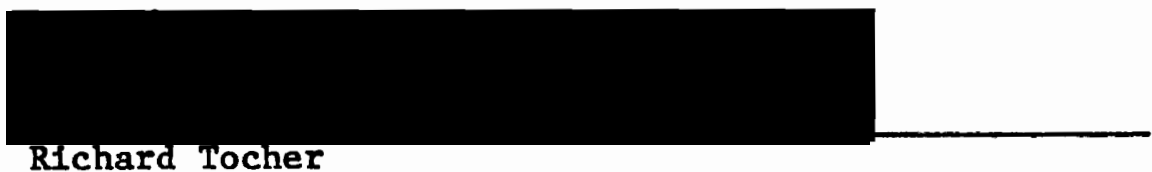

R1chard locher

APPROVED:

W. Herman Taylor, Jr., Head, Department of \$iology

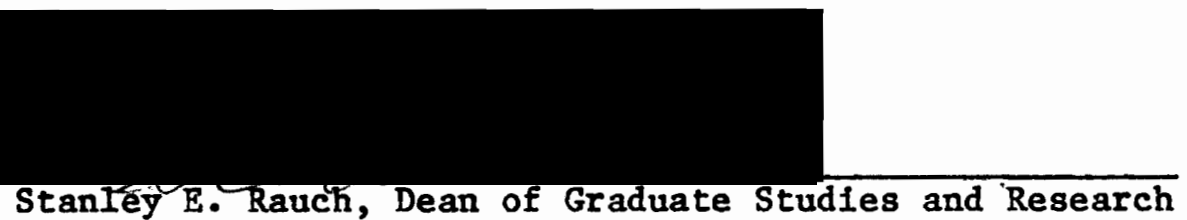




\section{ACKNOWLEDGEMENTS}

The author would like to extend her appreciation to her major advisor, Dr. Robert Tinnin, for his endless patience, advice, and welcomed sense of humor.

Appreciation is given to Dr. Lester Newman for his assistance in enlarging and printing the enclosed photographs.

Appreciation is extended to Sharon Peterson for her technical assistance.

Finally, appreciation is given to Marianne Itkin for her advise and support. 
TABLE OF CONTENTS

PAGE

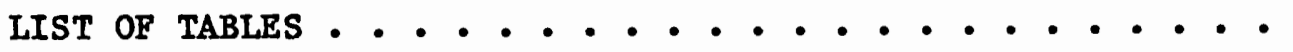

LIST OF FIGURES

$\nabla 111$

INTRODUCTION . . . . . . . . . . . . . . . . . . .

Life History of Arceuthoblum americanum

MATERIALS AND METHODS

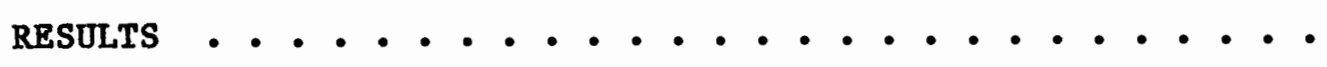

DISCUSSION . . . . . . . . . . . . . . . . .

CONCLUSIONS

LITERATURE CITED . . . . . . . . . . . . . . . .

APPENDIX A - RESULTS OF TWO WAY ANOVA COMPARING BRANCH CLASSIFICATIONS OF A GIVEN DMR . • • • • • •

APPENDIX B - RESULTS OF TWO WAY ANOVA COMPARING INFECTION LEVELS OF A GIVEN BRANCH CLASSIFICATION • • • • •

APPENDIX C - MEAN VALUES FOR MEASURED VARIABLES - • • • • •

APPENDIX D - SAMPLE SIZES . . . . . . . . . . . . . . 


\section{LIST OF TABLES}

TABLE

PAGE

I Climatological Data from 1975-1979 . . . . . . 9

II Mean Growth Characteristics of Sample Trees . . . . 10

III Analysis of Soll Samples from Study Sites . . . . 19

IV Analysis of Branch Classifications from Pinus contorta Infected with Arceuthobium americanum at SIsters Using One Way ANOVA . . . . . . . . .

$\nabla \quad$ Analysis of Branch Classifications from Pinus contorta Infected with Arceuthobium americanum at Crescent Using One Way ANOVA ..........

VI Results of DMR Analysis Using Two Way Nested ANOVA . . . . . . . . . . . . . . . . . .

VII Results of Branch Classification Analysis Using Two Way Nested ANOVA . . . . . . . . . . .

VIII Comparison of Branch Growth Characteristics of Pinus contorta and Pseudotsuga menziesii . . . . .

IX Sample Sizes Needed to Account for Observed

Varlation at Sisters . . . . . . . . . . .

X Sample Sizes Needed to Account for Observed

Variation at Crescent . . . . . . . . . .

XI Analysis of Branch Classifications from Pinus contorta Infected with Arceuthobium americanum at Crescent Using Two Way ANOVA--Twig Length . . .

XII Analysis of Branch Classifications from Pinus contorta Infected with Arceuthobium americanum at S1sters Using Two Way ANOVA--Twig Length . . .

XIII Analysis of Branch Classifications from Pinus contorta Infected with Arceuthobium americanum at Crescent Using Two Way ANOVA-Needle Number . . . 
XIV Analysis of Branch Classifications from Pinus contorta Infected with Arceuthobium americanum

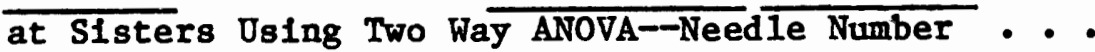

XV Analysis of Branch Classifications from Pinus contorta Infected with Arceuthoblum americanum at Crescent Using Two Way ANOVA-Total Segment

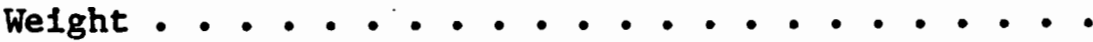

XVI Analysis of Branch Classifications from Pinus contorta Infected with Arceuthobium americanum at S1sters Using Two Way ANOVA-Total Segment Welght . . . . . . . . . . . . . . . . .

XVII Analysis of Branch Classifications from Pinus contorta Infected with Arceuthobium americanum at Crescent Using Two Way ANOVA-Average Needle Length . . . . . . . . . . . . . . . . .

XVIII Analysis of Branch Classifications from Pinus contorta Infected with Arceuthoblum americanum at Sisters Using Two Way ANOVA-Average Needle Length . . . . . . . . . . . . . . . .

XIX Analysis of Infection Levels of Pinus contorta Infected with Arceuthoblum americanum at Crescent Using Two Way ANOVA--Twig Length . . . . . . . .

XX Analysis of Infection Levels of Pinus contorta Infected with Arceuthoblum americanum at S1sters Using Two Way ANOVA-CTig Length : . . . . . . .

XXI Analysis of Infection Levels of Pinus contorta Infected with Arceuthoblum americanum at Crescent Using Two Way ANOVA-Needle Number . . . . . . .

XXII Analysis of Infection Levels of Pinus contorta Infected with Arceuthobium americanum at Sisters Using Two Way ANOVA-Needle Number .........

XXIII Analysis of Infection Levels of Pinus contorta Infected with Arceuthoblum americanum at Crescent Using Two Way ANOVA-Total Segment Weight . . . .

XXIV Analysis of Infection Levels of Plnus contorta Infected with Arceuthoblum americanum at S1sters Using Two Way ANOVA-Total Segment Weight . . . . 
XXV Analysis of Infection Levels of Pinus contorta Infected with Arceuthobium americanum at Crescent Using Two Way ANOVA-Average Needle Length . . . .

XXVI Analysis of Infection Levels of Pinus contorta Infected with Arceuthoblum americanum at Sisters Using Two Way ANOVA--Average Needle Length . . . .

XXVII Mean Values for Measured Variables at Crescent . . . 58

XXVIII Méan Values for Measured Variables at S1sters . . 60

XXIX Sample Sizes ................ 63 


\section{LIST OF FIGURES}

FIGURE

PAGE

1. Aerial Shoots of Arceuthobium americanum . . . . - 5

2. Sisters Site .................. . 8

3. Crescent Site . . . . . . . . . . . . 12

4. The 6-Class Dwarf Mistletoe Rating System .....' 13

5. Systemic Brooms on Pinus contorta Infected with Arceuthobium americanum . . . . . . . . . 15

6. Systemlc Broom of Arceuthobium americanum on

Pinus contorta . . . . . . . . . . . . . 16 


\section{INTRODUCTION}

Arceuthobium comprises approximately 40 taxa of flowering plants commonly referred to as dwarf mistletoes. Members of this genus parasitize all of the specles of the family Pinaceae which occur in the Pacific Northwest (Hawksworth and Weins, 1972), although some only occasionally. Members of the genus Arceuthobium can meet only 25 to 30 percent of their own energy requirements through photosynthesis (Hull and Leonard, 1964 and Miller and Tocher, 1975). The remaining energy must be obtained from the host. This places a demand on the host which often results in a change In host growth patterns and early host death (ChIlds and Shea, 1967).

In the Pacific Northwest, conifer species are a very valuable resource. Because of this, the reported damage caused by Arceuthoblum 8pp. is usually assessed in terms of damage to or 1088 of fiber or lumber.

In a 1979 assessment of dwarf mistletoe damage to Pinus contorta (Lodgepole pine) on Colorado National Forest lands, it was found that 46.6 percent of the trees were infected with A. americanum. This represents a $108 \mathrm{~s}$ of $8.9 \mathrm{cu} \mathrm{ft} / \mathrm{A} / \mathrm{yr}$ of merchantable timber (Johnson, Hawksworth, and Drummond, 1980). A 1972 survey of Oregon, Washington, and California reported that $1.4 \times 10^{6}$ of $2.5 \times 10^{6}$ acres of $\underline{P}$. contorta (57 percent) were infected with A. americanum (Bolsinger, 1978). In Alberta, Canada the annual timber 108 s of $\underline{P}$. contorta and 
P. banksiana attributable to Arceuthobium spp. is $9,582,000 \mathrm{cu}$ ft. This places dwarf mistletoe as the number one disease of pine in the Province of Alberta (Baranyay, 1970).

Dwarf mistletoes are also known to cause tree death. In stands heavily infected with Arceuthobium spp., mortality rates were found to be twice the rates of healthy stands (Gill and Hawskworth, 1964). Research limited to $\underline{P}$. contorta concluded that young infected stands did not exhibit any increase in mortality over healthy stands (Baranyay and Safranyik, 1970). This situation changed when mature stands of $P$. contorta were observed. It was reported that the mortaility rate for mature stands of $\underline{P_{-}}$contorta infected with $\mathrm{A}_{-}$ americanum was 26 percent higher than healthy stands (Baranyay and Safranyik, 1970).

Much of the timber loss is not a decrease in tree volume but in timber quality. A. americanum infected $\underline{P}$. contorta are often observed having large knots, stem cankers, and other wood abnormalIt1es (GIIl and Hawksworth, 1964).

Although the above data concretely demonstrate that Arceuthobium spp. causes measurable reduction in the productivity of forests, 1ittle Information is available concerning the damage done by Arceuthobium spp. to the limbs of individual trees. Preliminary research indicates that there is a difference in twig growth between healthy branches and branches heavily infected with Arceuthobium spp. Heavily infected branches of Pseudotsuga menziesil were reported to be longer and have a greater biomass than healthy branches. Needles from 
Infected branches were more numerous and had a lower blomass than needles from healthy branches (TInnin and Rnutson, 1980).

The purpose of this study was to collect detalled preliminary data on effects of Arceuthoblum americanum Nutt. 1 on twig length, needle length, needle number, and combined twig and needle blomass of one host, Pinus contorta var. latifolia Engelm. It was speculated that these variables would demonstrate a difference in host branch growth with varying degrees of parasite infection. The results are compared to the previously published data on Pseudotsuga menziesil, and they provide a basis for evaluating the usefulness of exhaustive studies of this kind of the growth of infected P. contorta.

1 All sclentific names used are from Hitchcock and Cronquist, 1973. 
LIFE HISTORY OF Arceuthobium americanum

Arceuthobium americanum is a parasitic flowering plant found growing primarily on Plnus contorta (f1g. I). This dwarf mistletoe specles is also found parasitizing P. banksiana, P. ponderosa, and occaslonally other conlfer specles (Hawksworth and Wiens, 1972.) Hawksworth (1965) outlined the complete life history of A. americanum. Flowering of this species of Arceuthobium occurs in April and May. The plants are dloeclous and the flowers are highly reduced and boin on vegetative stalks (called aerlal shoots) protruding from the host stem. These shoots are photosynthetic and are the only portions of the parasite external to the host. A. americanum is wind pollenated (Whitehead, 1969). Mature fruits are released in August and September of the year following pollination.

Each frult contalns a single seed (Hawksworth and Wiens, 1972). The seed is dispersed explosively up to a distance of about $10 \mathrm{~m}$ from 1ts host. Dwarf mistletoe seeds are covered with a sticky gelatinous substance called viscin. Viscin allows the seed to adhere to any object it encounters in its path of flight. The seeds are often intercepted by needles or twigs of the host tree or of a nelghboring tree, although a large number of seeds are not intercepted and are 108t. Rain causes the viscin to become slippery and allows the seeds on the needles to slide to the twig where germination occurs in the following spring.

The parasite radical penetrates and grows into the host tissue. A swelling of host tissue often occurs following penetration by the 


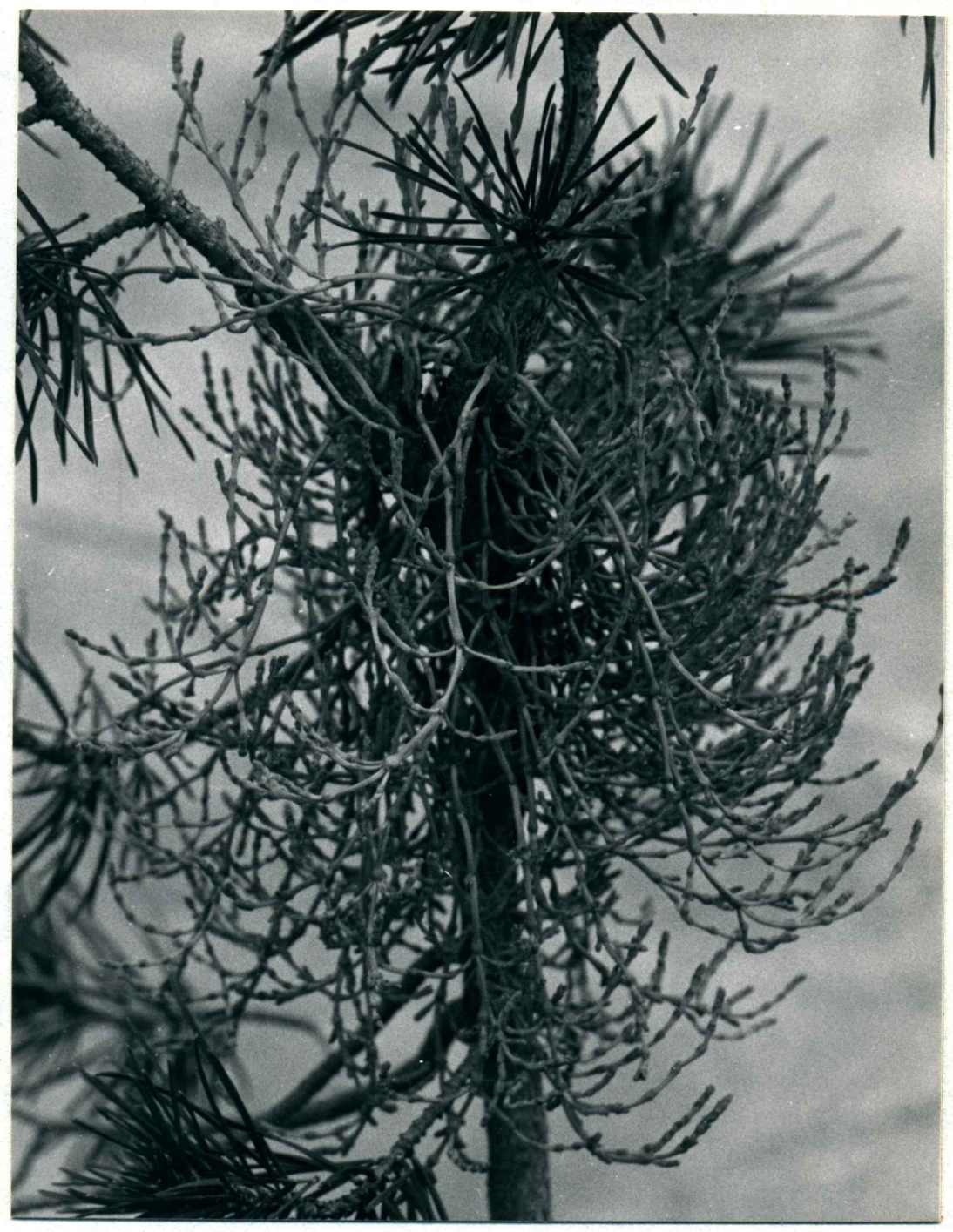

Figure 1. Aerial Shoots of Arceuthobium americanum 
parasite.

After 2 to 6 years from the time of infection, A. americanum

w11 begin to produce aerlal shoots. These shoots immediately begin to produce flowers. 
MATERIALS AND METHODS

Site Selection and Description

Two sample sites were chosen and were composed of essentlally pure stands of Pinus contorta infected with Arceuthobium americanum. The two sites were chosen to provide a wide range of infection levels. Both sites were located on the east side of the Cascade Mounta1n Range.

The first site was located $21 \mathrm{~km}$ south of the town of sisters, Oregon on road 1534 (Sections $34 \& 35, \mathrm{R} 9 \mathrm{E}, 16 \mathrm{~S}$, W11lamette Meridian). It will be referred to as the "Sisters" site (fig. 2). It was located on a very slight slope at an elevation of $1780 \mathrm{~m}$. Rainfall at the town of S1sters averaged $32.9 \mathrm{~cm}$ for the years 1975 through 1979, with an average July temperature of $17.5^{\circ} \mathrm{C}$ and an average January temperature of $-1.3^{\circ} \mathrm{C}$ for the same years (Table I).

This stand of trees was moderately to heavily infected with A. americanum. Density of $\underline{P}$. contorta was $1.2 \mathrm{trees} / \mathrm{m}^{2}$ with a 0.28 trees/m $/ \mathrm{m}^{2}$ density of climax trees. A random sample of climax trees Indicated that the average age was 83.76 years, dlameter at breast helght (DBH) was $24.80 \mathrm{~cm}$, height was $16.92 \mathrm{~m}$, with an estimated lateral growth rate of $0.30 \mathrm{~cm} / \mathrm{yr}$ (Table II).

Ground cover was scarce and primarily composed of Lupinus spp. and unidentifled grasses. 


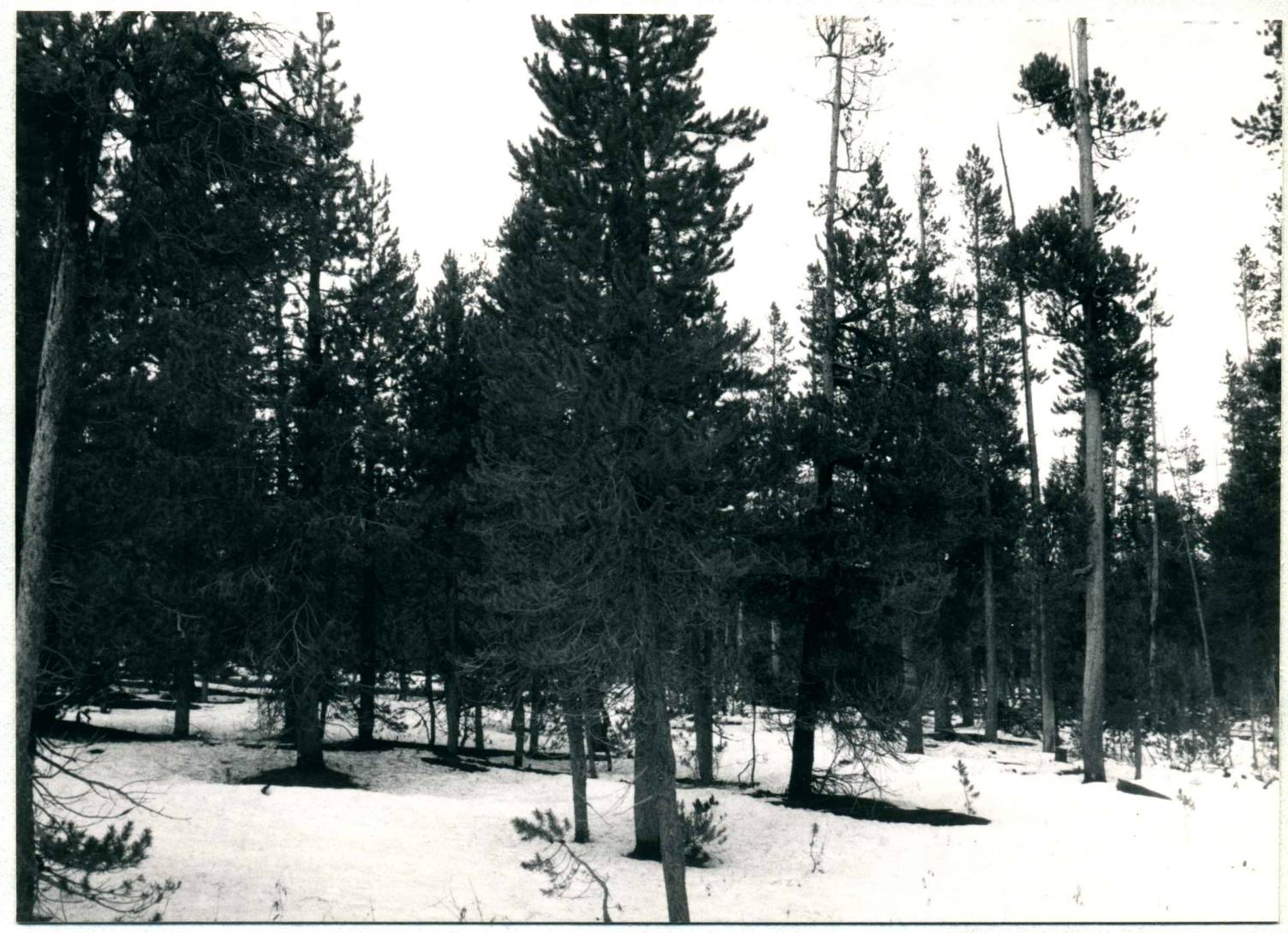

Figure 2. Sisters Site 


\section{TABLE I}

CLIMATOLOGICAL DATA FROM 1975-1979

(Temperature ${ }^{\circ} \mathrm{C}$ )

Chemulta

Annual.

Rainfall

\begin{tabular}{|c|c|c|c|c|c|c|c|}
\hline Year & Jan & Feb & Jun & Jul & Aug & Dec & (cm) \\
\hline $\begin{array}{l}1975 \\
1976 \\
1977 \\
1978 \\
1979\end{array}$ & $\begin{array}{l}-3.3 \\
-2.5 \\
-5.2 \\
-0.1 \\
-7.6\end{array}$ & $\begin{array}{r}-2.6 \\
-2.1 \\
0.4 \\
-0.8 \\
-1.1\end{array}$ & $\begin{array}{l}10.5 \\
10.0 \\
14.4 \\
12.1 \\
12.6\end{array}$ & $\begin{array}{l}16.4 \\
15.3 \\
15.2 \\
15.6 \\
15.7\end{array}$ & $\begin{array}{l}13.2 \\
12.7 \\
16.9 \\
14.9 \\
14.4\end{array}$ & $\begin{array}{r}-0.8 \\
-4.2 \\
-1.8 \\
\mathrm{mb} \\
-\mathrm{c}\end{array}$ & $\begin{array}{l}81.9 \\
36.5 \\
64.3 \\
48.5 \\
61.3\end{array}$ \\
\hline Mean & -3.7 & -1.2 & 11.9 & 15.6 & 14.4 & -2.3 & 58.5 \\
\hline
\end{tabular}

\section{Sistersd}

Annual

Rainfall

\begin{tabular}{|c|c|c|c|c|c|c|c|}
\hline Year & Jan & Feb & Jun & JuI & Aug & Dec & (cm) \\
\hline $\begin{array}{l}1975 \\
1976 \\
1977 \\
1978 \\
1979\end{array}$ & $\begin{array}{r}-3.4 \\
0.8 \\
-2.8 \\
0.3 \\
\mathrm{mb}\end{array}$ & $\begin{array}{r}-1.1 \\
0.9 \\
3.7 \\
1.9 \\
1.1\end{array}$ & $\begin{array}{l}12.2 \\
11.7 \\
16.3 \\
14.7 \\
12.4\end{array}$ & $\begin{array}{l}18.4 \\
17.7 \\
16.4 \\
17.6 \\
17.5\end{array}$ & $\begin{array}{l}14.7 \\
15.1 \\
19.7 \\
15.8 \\
15.8\end{array}$ & $\begin{array}{r}1.6 \\
-0.7 \\
0.9 \\
\mathrm{~m}^{\mathrm{b}} \\
-\mathrm{c}\end{array}$ & $\begin{array}{l}42.5 \\
27.9 \\
32.2 \\
32.6 \\
29.6\end{array}$ \\
\hline Mean & -1.3 & 1.3 & 13.4 & 17.5 & 16.2 & 0.6 & 32.9 \\
\hline
\end{tabular}

\footnotetext{
a Located approximately $10 \mathrm{~km}$ SSE of Crescent site.

b Data missing.

c Not reported.

d Located approximately $18 \mathrm{~km} \mathrm{NNE}$ of Sisters site.
} 
TABLE II

MEAN GROWTH CHARACTERISTICS

OF SAMPLE TREES

\section{Sisters}

\begin{tabular}{|c|c|c|c|c|}
\hline DMR & $\begin{array}{l}\text { Average } \\
\text { Age (yr) }\end{array}$ & $\begin{array}{l}\text { Average } \\
\text { DBH (cm) }\end{array}$ & $\begin{array}{c}\text { Average } \\
\text { Height (m) }\end{array}$ & $\begin{array}{l}\text { Average } \\
\text { Lateral } \\
\text { Growth } \\
\text { (cm/yr) }\end{array}$ \\
\hline 3 & 71.25 & 23.40 & 15.95 & 0.33 \\
\hline 4 & 64.80 & 25.40 & 17.78 & 0.39 \\
\hline 5 & 80.23 & 26.50 & 16.84 & 0.33 \\
\hline 6 & 94.00 & 24.00 & 17.11 & 0.25 \\
\hline GRAND & 83.76 & 24.80 & 16.92 & 0.30 \\
\hline
\end{tabular}

Crescent

\begin{tabular}{|c|c|c|c|c|}
\hline & $\begin{array}{c}\text { Average } \\
\text { Age (yr) }\end{array}$ & $\begin{array}{c}\text { Average } \\
\text { DBH (cm) }\end{array}$ & $\begin{array}{c}\text { Average } \\
\text { Average } \\
\text { Lateral }\end{array}$ & $\begin{array}{c}\text { Growth } \\
\text { (cm/gr) }\end{array}$ \\
\hline 1 & 69.00 & 22.90 & 17.03 & 0.33 \\
\hline 2 & 72.33 & 23.50 & 15.62 & 0.32 \\
\hline 3 & 80.25 & 27.50 & 21.06 & 0.31 \\
\hline 4 & 86.67 & 29.40 & 18.63 & 0.34 \\
\hline 5 & 89.00 & 27.50 & 17.80 & 0.26 \\
\hline GRAND & 79.45 & 26.20 & 18.03 & 0.33 \\
\hline
\end{tabular}


The second site was located southeast of Crescent Lake (Section 29, R7E, 24S, W1llamette Meridian). It w111 be referred to as the "Crescent" site (f1g. 3).

It was located on a relatively flat area at an elevation of $1442 \mathrm{~m}$ above sea level. Rainfall at the nearby town of Chemult averaged $58.5 \mathrm{~cm}$ for the years 1975 through 1979, w1th an average July temperature of $15.6^{\circ} \mathrm{C}$ and an average January temperature of $-3.7^{\circ} \mathrm{C}$ (Table I).

This stand of trees was uninfected to heavily infected with A. americanum. Density of $\underline{P}$. contorta was 1.8 trees $/ \mathrm{m}^{2}$ with a 0.15 trees $/ \mathrm{m}^{2}$ density of climax trees. A random sample of climax trees Indicated that the average age was 79.45 years, DBH was $26.20 \mathrm{~cm}$, helght was $18.03 \mathrm{~m}$, and the estimated lateral growth rate was $0.33 \mathrm{~cm} /$ yr (Table 2).

Ground cover was scarce and primarily composed of unidentifled grasses and small shrubs.

\section{Sample Selection}

Each site was subdivided into nine 1-hectare plots. Three sample plots were randomly chosen from among the group at each site. Sample trees were then chosen from these plots.

Within the sample plots, all dominant trees were considered possible research Individuals, with the exception of spike-topped and double-trunked trees. The acceptable trees were rated according to theirs level of infection with A. americanum from 0 to 6,0 denoting an uninfected tree, and 6 denoting a tree whose entire crown is heavily 


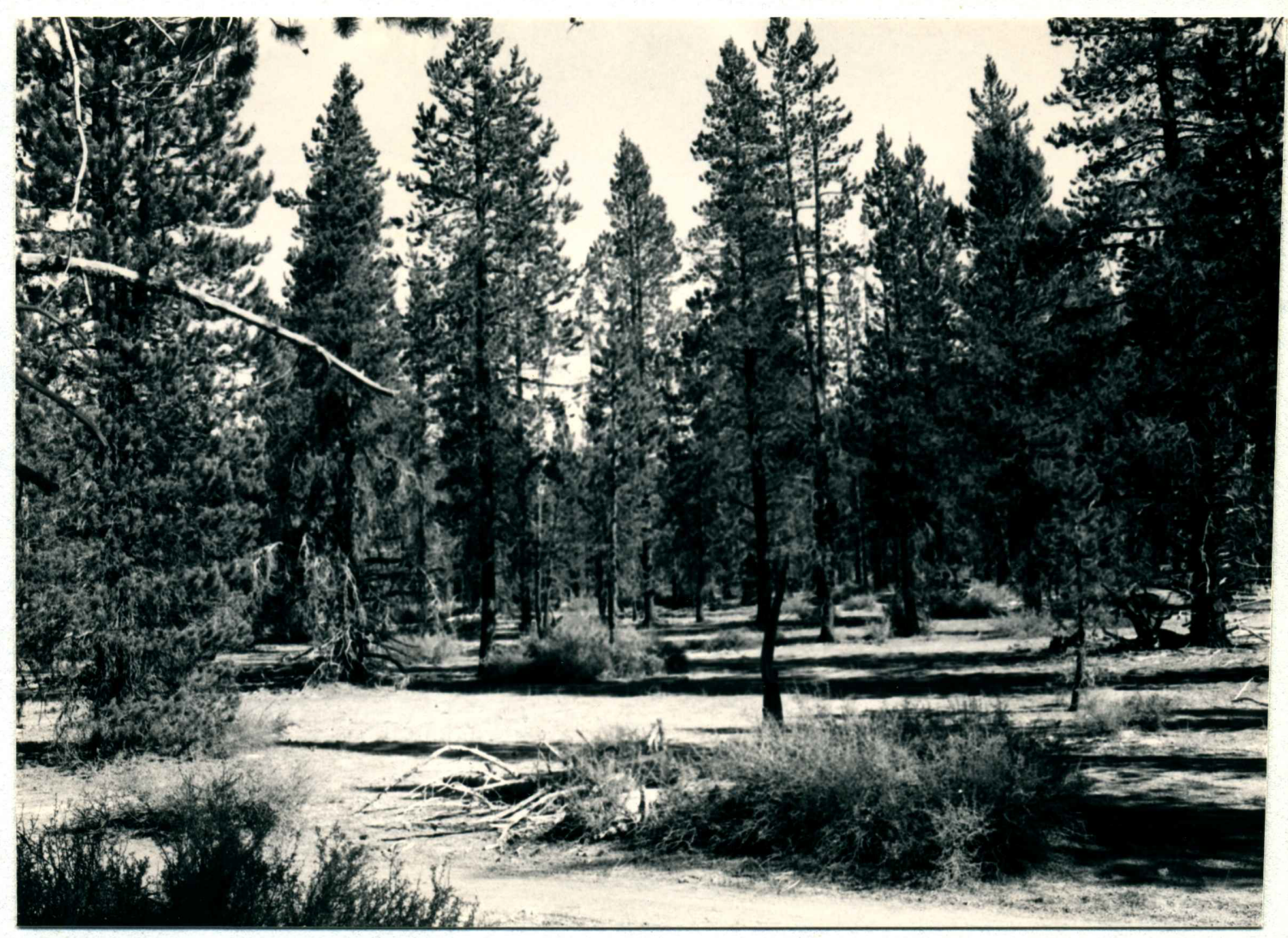

Figure 3. Crescent Site 


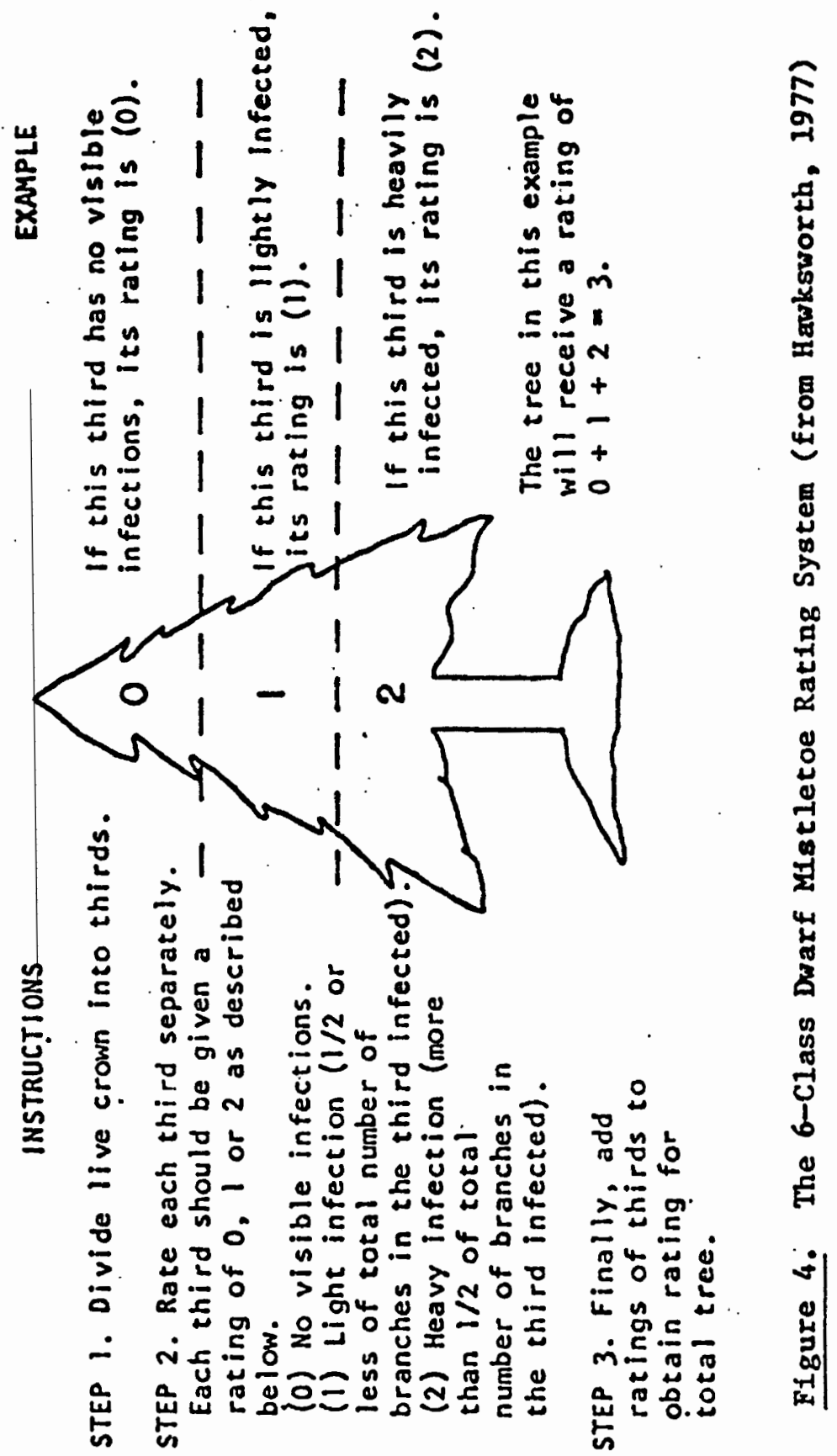


infected with A. americanum (fig. 4) [Hawksworth, 1977] - This numerical code will be referred to as the dwarf mistletoe rating (DMR) of the trees.

From each plot, six trees were randomly selected from each DMR present. Branch samples were taken from these trees.

Three branches were taken from the southeast side of each tree. Samples were taken at a helght of approximately $6.0 \mathrm{~m}$ above ground level. A core was taken from each tree at breast helght to determine age. The approximate height of each tree was determined with the aid of an inclinometer.

As the samples were collected, each branch was classified accordIng to the type of A. americanum infection present. The sample was designated uninfected, locally infected, or part of a systemic broom. A branch was considered locally infected when 1solated point infections were observed. These Infections were identified by branch swellings often accompanied by aerlal shoots. A systemic broom was typlfled by a dense array of twigs having a globulous appearance and originating from a single branch (figs, 5 and 6 ). The mistletoe was spread throughout the entire broom (Baranyay, 1970). The type of infection present will be referred to as the branch classification.

\section{Data Collection and Analys1s}

A soll sample was taken from a central point in each study site for analysis at the Soll Testing Laboratory, Oregon State UnIversity. Each sample was analyzed for $\mathrm{pH}$, varlous inorganic ions, organic 


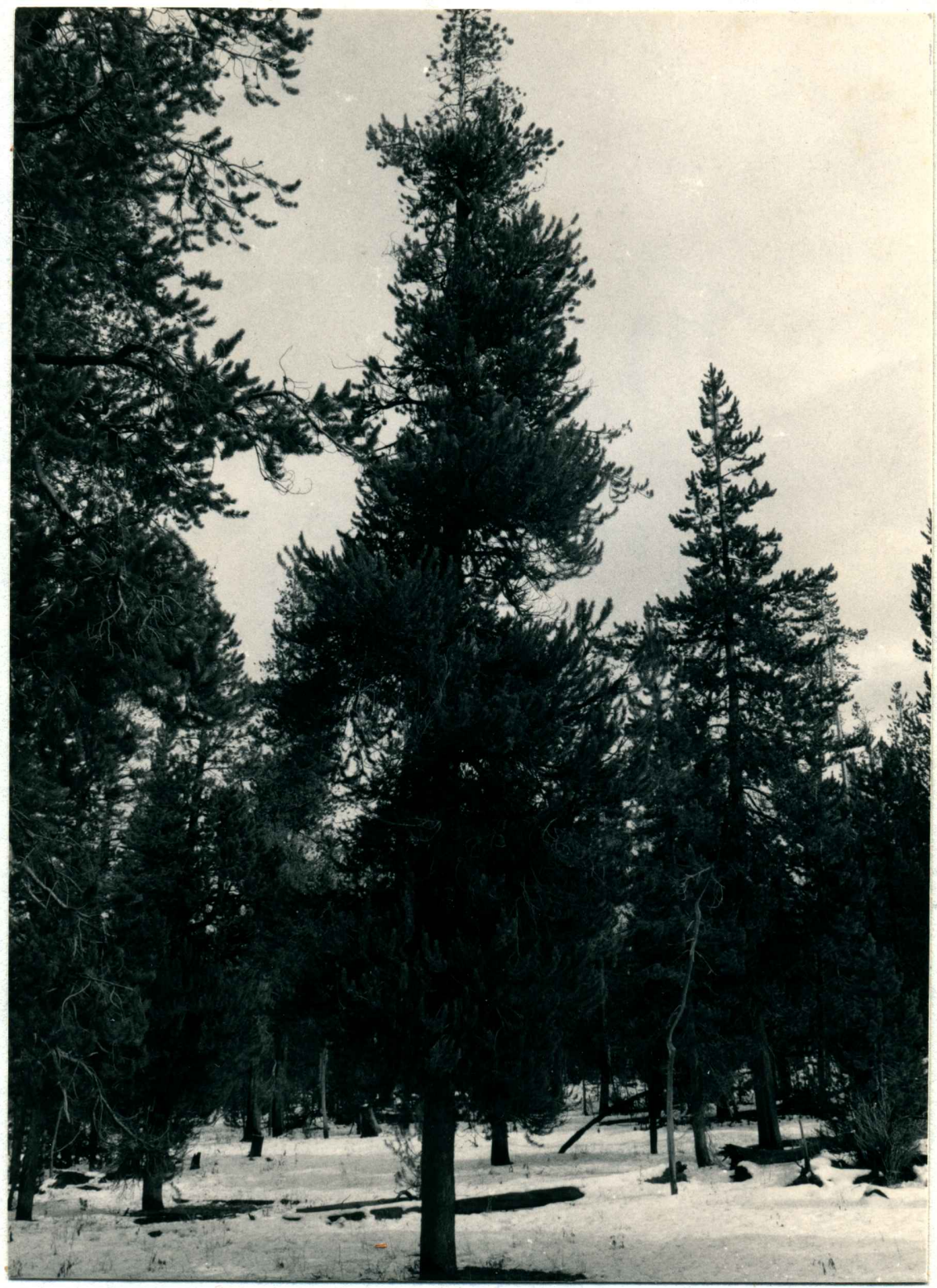

Figure 5. Systemic Brooms on Pinus contorta Infected with Arceuthobium americanum 


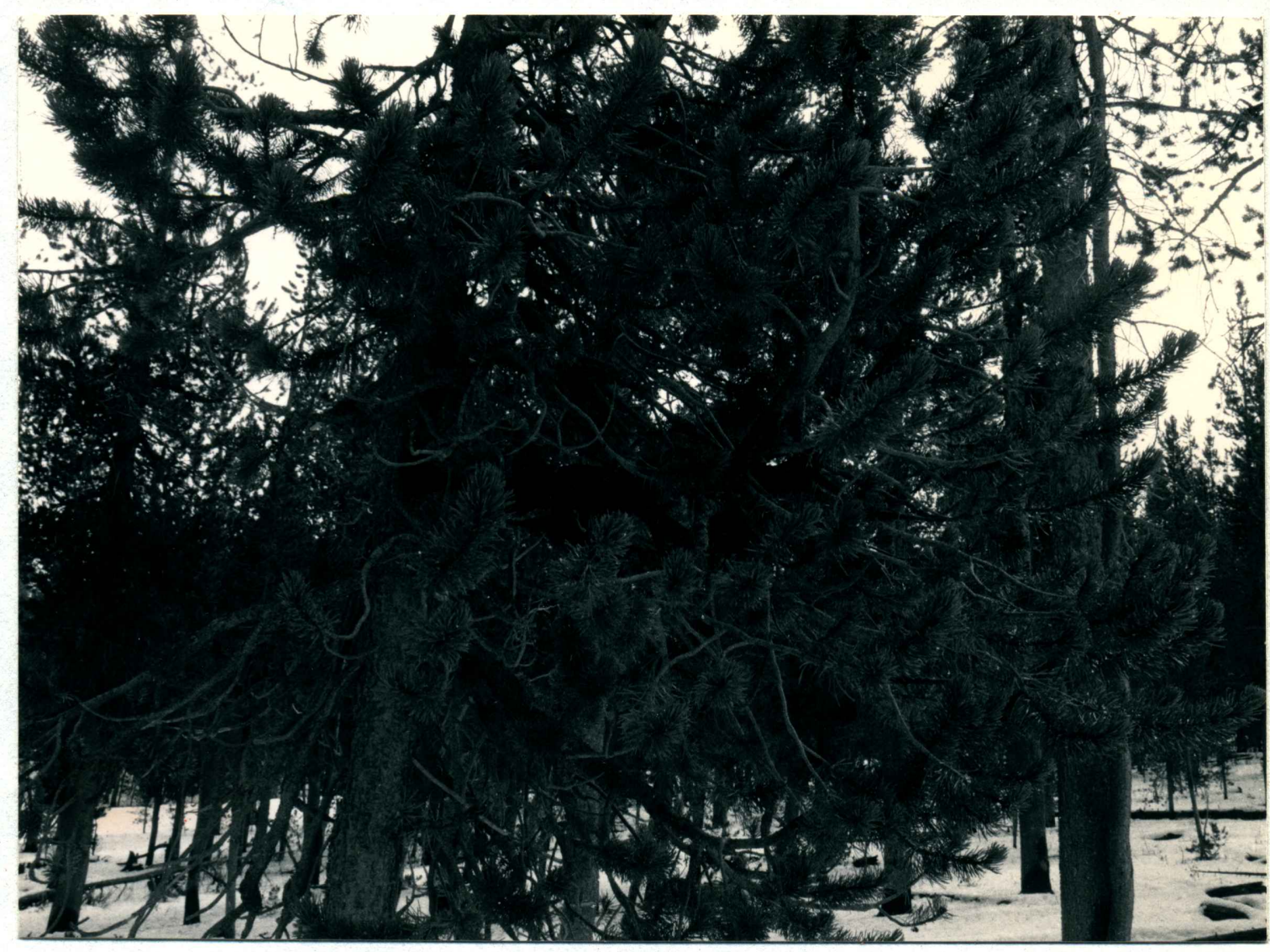

Figure 6. Systemic Broom of Arceuthobium americanum on Pinus contorta 
matter, cation exchange capacity, and percent moisture by weight. These variables may Influence tree growth.

Data on twig growth were recorded from the four most recent years of twig growth (1976-1979) from each sample collected. The year segments were identified by bud scars. For each year the following varlables were measure: twig length, needle number, needle length, and total segment (needle and twig combined) dry welght. Twig and needle lengths were measured to the nearest $1.0 \mathrm{~mm}$. Segment dry weight was recorded to the nearest $10^{-5} \mathrm{gm}$. The data were, depending on the specific treatment, analyzed by means of one way analysis of variance (ANOVA) or two way nested ANOVA (Sokal and Rohlf, 1969). Determination of required sample sizes, based on observed variance, was completed following the procedure outlined by Brower and Zar (1977). I tests were completed on selected values (Sokal and Rohlf, 1969). 


\section{RESULTS}

\section{Site Comparison}

Baseline data were collected to determine if the two sites were comparable with respect to several physical variables and to general growth characteristics of trees found at each site. This procedure was used to determine how best the data from the two sites might be treated in later studies.

Table I summarizes climatological data recorded near the two sites. The differences in temperature were not great; the difference in rainfall was large.

Table II summarizes mean values for the data collected on tree growth at each site. Although there is not a significant difference In the overall lateral growth rate between trees at the two sites, there are differences between the sites at a given DMR as determined by $t$ tests. These data illustrate the difference in tree growth between the two sites.

Table III is a summary of the analysis of soil samples from the two sites. The observed differences suggest different growth potentials for trees at the two sites. Without a more thorough treatment of soil conditions, the actual impact on tree growth remains unknown. Iimitation of funds prevented a more detailed evaluation as part of this study. 


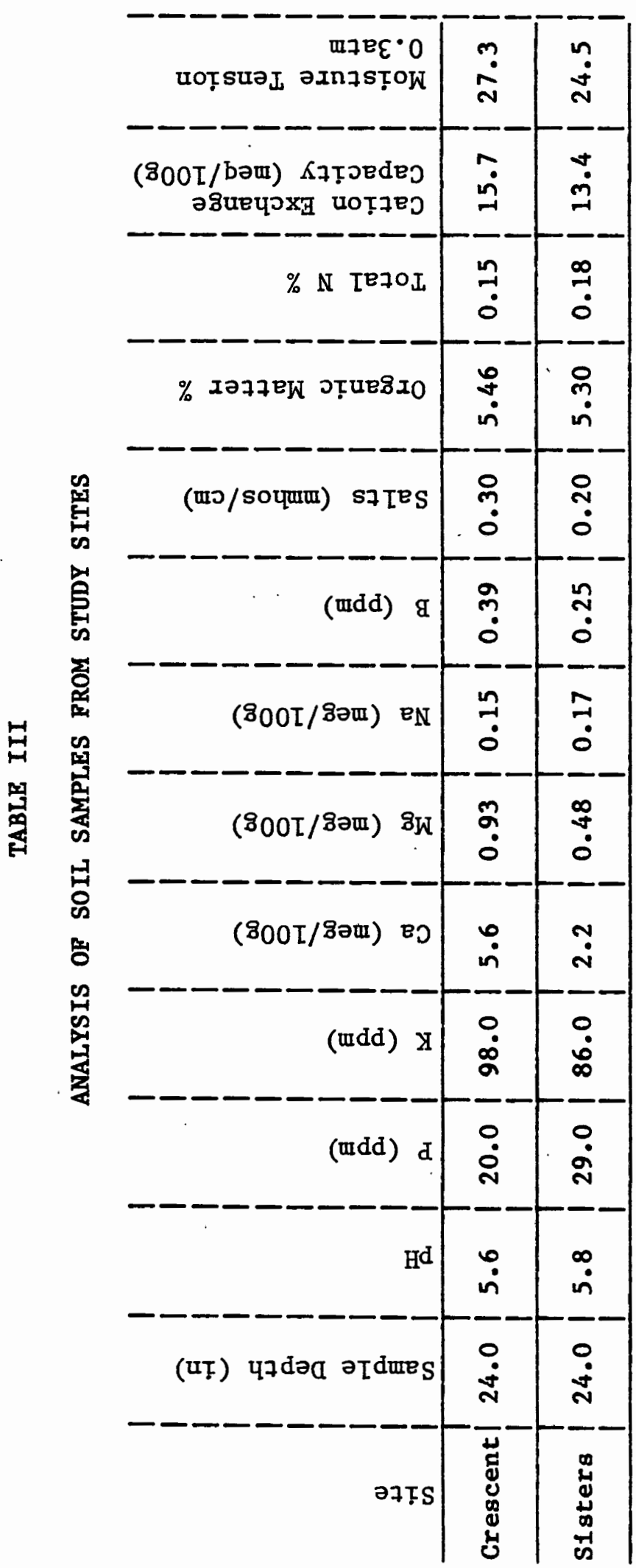


On the basis of the observed differences of solls and of tree growth, I w11l not assume there is even approximate equivalence of potential for tree growth at the two sites. The data from the two sites are therefore analyzed separately.

\section{Analysis of Growth Variables}

Growth from the year 1978 was treated by means of one way ANOVA and two way nested ANOVA. This segment represents mature tissue that has not begun to deterforate.

One way ANOVA was used to test the simflarity between the four sampled variables of branch growth from uninfected branches, locally Infected branches, and systemically infected branches without consideration of the level of dwarf mistletoe infection.

At Sisters, samples were combined from DMR 3 through 6 for analysis. This analysis relates trees that were lightly infected to those that were heavily infected. When all samples were compared, regardless of DMR, a significant difference was observed between moderately and heavily infected samples in twig length, total segment dry welght, and average needle number (see Table IV).

At Crescent, samples were combined from DMR 0 through 5 for analysis. This represents trees that are uninfected to heavily infected. When these samples were compared, a significant difference was observed between needle number only (see Table V).

Each DMR was analyzed to determine if there were any significant differences in growth varlables between samples from the three branch classifications collected from given DMR. Two way nested ANOVA 
ANALYSIS OF BRANCH CLASSIFICATIONS FROM PINUS CONTORTA INPECTED WITH ARCEUTHOBIUM AMERICANUM AT SISTERS OS ING ONE WAY ANOVA

\begin{tabular}{|c|c|c|c|c|c|}
\hline \multicolumn{2}{|c|}{ Source of Varlation } & $\operatorname{df}[a]$ & SS [b] & $\operatorname{MS}[c]$ & $\mathbf{F}$ \\
\hline $\begin{array}{l}\text { Twig } \\
\text { Length }\end{array}$ & $\begin{array}{l}\text { Among Branch } \\
\text { Classification } \\
\text { Among Trees } \\
\text { Total }\end{array}$ & $\begin{array}{r}2 \\
131 \\
133\end{array}$ & $\begin{array}{r}6.31 \\
76.34 \\
82.65\end{array}$ & $\begin{array}{l}3.15 \\
0.58\end{array}$ & $5.41[\mathrm{~d}]$ \\
\hline $\begin{array}{l}\text { Needle } \\
\text { Number }\end{array}$ & $\begin{array}{l}\text { Among Branch } \\
\text { Classification } \\
\text { Among Trees } \\
\text { Total }\end{array}$ & $\begin{array}{r}2 \\
131 \\
133\end{array}$ & $\begin{array}{r}686.91 \\
49448.59 \\
50135.49\end{array}$ & $\begin{array}{l}343.45 \\
377.47\end{array}$ & $0.91[\mathrm{e}]$ \\
\hline $\begin{array}{l}\text { Total } \\
\text { Segment } \\
\text { Weight }\end{array}$ & $\begin{array}{l}\text { Among Branch } \\
\text { Classification } \\
\text { Among Trees } \\
\text { Total }\end{array}$ & $\begin{array}{r}2 \\
131 \\
133\end{array}$ & $\begin{array}{r}5.31 \\
33.24 \\
38.55\end{array}$ & $\begin{array}{l}2.66 \\
0.25\end{array}$ & $10.47[\mathrm{~d}]$ \\
\hline $\begin{array}{l}\text { Average } \\
\text { Needle } \\
\text { Length }\end{array}$ & $\begin{array}{l}\text { Among Branch } \\
\text { |Classification } \\
\text { |Among Trees } \\
\text { |Total }\end{array}$ & $\begin{array}{r}2 \\
131 \\
133\end{array}$ & $\begin{array}{r}3.72 \\
77.28 \\
80.99\end{array}$ & $\begin{array}{l}1.86 \\
0.59\end{array}$ & $3.15[f]$ \\
\hline
\end{tabular}

[a] - degrees of freedom

[b] - sum of squares

[c] - mean squares

[d] - significant at 0.01

[e] - not significant

[f] - significant at 0.05 
TABLE V

ANALYSIS OF BRANCH CLASSIFICATIONS FROM PINUS CONTORTA INEECTED WITH ARCEUTHOBIUM AMERICANUM AT CRESCENT USING ONE WAY ANOVA

\begin{tabular}{|c|c|c|c|c|c|}
\hline \multicolumn{2}{|c|}{ Source of Varlation } & $\mathrm{df}[\mathrm{a}]$ & $S S[b]$ & MS [c] & $\mathbf{F}$ \\
\hline $\begin{array}{l}\text { Twig } \\
\text { Length }\end{array}$ & $\begin{array}{l}\text { Among Branch } \\
\text { Classification } \\
\text { Among Trees } \\
\text { Total }\end{array}$ & $\begin{array}{r}2 \\
105 \\
107\end{array}$ & $\begin{array}{r}2.15 \\
58.47 \\
50.63\end{array}$ & $\begin{array}{l}1.08 \\
0.56\end{array}$ & $1.93[\mathrm{~d}]$ \\
\hline $\begin{array}{l}\text { Needle } \\
\text { Number }\end{array}$ & $\begin{array}{l}\text { Among Branch } \\
\text { Classification } \\
\text { Among Trees } \\
\text { Total }\end{array}$ & $\begin{array}{r}2 \\
109 \\
111\end{array}$ & $\begin{array}{l}5200.32 \\
43141.36 \\
48341.68\end{array}$ & $\begin{array}{r}2600.16 \\
395.79\end{array}$ & $6.57[\mathrm{e}]$ \\
\hline $\begin{array}{l}\text { Total } \\
\text { Segment } \\
\text { Welght }\end{array}$ & $\begin{array}{l}\text { Among Branch } \\
\text { Classification } \\
\text { Among Trees } \\
\text { Total }\end{array}$ & $\begin{array}{r}2 \\
106 \\
108\end{array}$ & $\begin{array}{r}0.93 \\
25.94 \\
26.87\end{array}$ & $\begin{array}{l}0.47 \\
0.24\end{array}$ & $1.90[d]$ \\
\hline $\begin{array}{l}\text { Average } \\
\text { Needle } \\
\text { Length }\end{array}$ & $\begin{array}{l}\text { Among Branch } \\
\text { Classiflcation } \\
\text { Among Trees } \\
\text { Total }\end{array}$ & $\begin{array}{r}2 \\
105 \\
107\end{array}$ & $\begin{array}{r}0.08 \\
78.51 \\
78.59\end{array}$ & $\begin{array}{l}0.04 \\
0.75\end{array}$ & $0.05[d]$ \\
\hline
\end{tabular}

[a] - degrees of freedom

[b] - sum of squares

[c] - mean squares

[d] - not significant

[e] - significant at 0.01 
nested ANOVA was used to Indicate variation between branch classifications. Table VI summarizes the results of this procedure. Detailed results are listed in Appendix A.

Two way nested ANOVA produced mixed results at both sites when branch classifications of a given DMR were compared.

At Crescent, twig length was useful in noting varlation between branch classifications for samples from DMR 3 and 4 . Needle number distinguished between branch classifications of DMR 3 only. Total segement welght discriminated between branch classifications of DMR 4 . Average needle number separated branch classifications of DMR 1 . At Sisters, a significant level of variation was noted between branch classificatons of DMR 3 for the varlable twig length. Needle number discriminated between branch classificaltons of DMR 4 . Total segment weight was useful in separating branch classifications of DMR 4. Average needle length allowed discrimination between branch classifications of DMR 4, 5, and 6 .

Each branch classification was also analyzed using two way nested ANOVA to determine if there were any significant differences In the growth of samples collected from varying DMRs but of only one branch classification. Table III summarizes the results of this procedure. Detalled results are listed in Appendix B.

At Crescent, the four growth varlables measured noted variation bewteen DMRs when locally infected samples were compared.

At Sisters, twig length discriminated between samples from varying DMRs only when the samples were systemically infected. Needle number noted differences between DMRs of locally infected 


\section{TABLE VI}

RESULTS OF DMR ANALYSIS USING

TWO WAY NESTED ANOVA

Crescent

\begin{tabular}{|l|c|c|}
\hline Varlable & DMR & $\begin{array}{c}\text { Level of } \\
\text { Significance* }\end{array}$ \\
\hline Tw1g & 1 & ns \\
Length & 3 & 0.05 \\
& 4 & 0.05 \\
\hline Needle & 1 & ns \\
Number & 3 & 0.05 \\
& 4 & ns \\
\hline Total & 1 & ns \\
Segment & 3 & ns \\
Welght & 4 & 0.5 \\
\hline Average & 1 & 0.05 \\
Needle & 3 & ns \\
Number & 4 & ns \\
\hline
\end{tabular}

S1sters

\begin{tabular}{|l|c|c|}
\hline Varlable & DMR & $\begin{array}{c}\text { Level of } \\
\text { Significance* }\end{array}$ \\
\hline Tw1g & 3 & 0.05 \\
Length & 4 & ns \\
& 5 & ns \\
\hline Needle & 6 & ns \\
Number & 4 & ns \\
& 5 & 0.05 \\
& 6 & ns \\
\hline Total & 3 & ns \\
Segment & 4 & ns \\
Weight & 5 & 0.05 \\
& 6 & ns \\
\hline Average & 3 & ns \\
Needle & 4 & ns \\
Number & 5 & 0.05 \\
& 6 & 0.01 \\
\hline
\end{tabular}

*. ns = not significant 


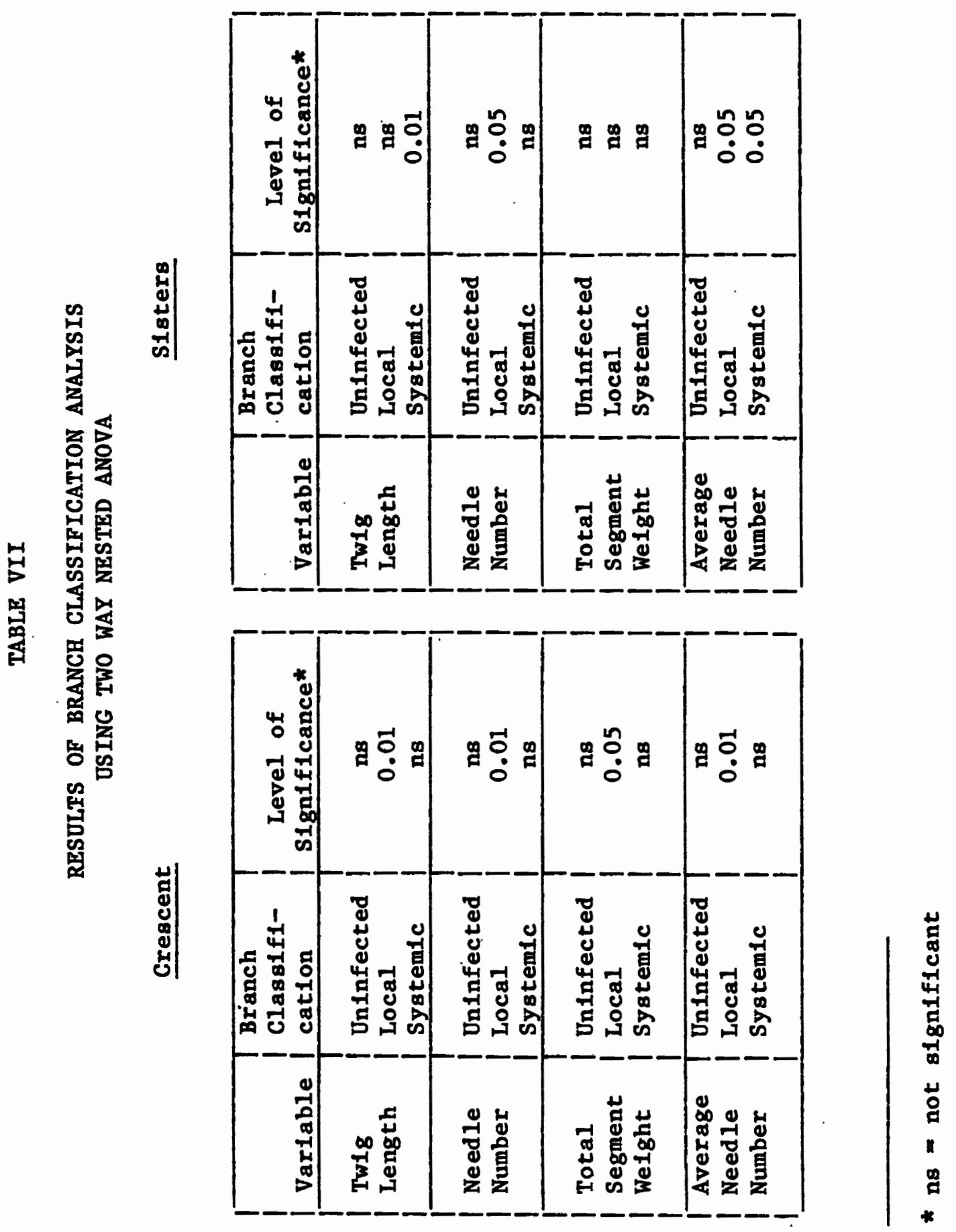


samples. Average needle number was useful in separating DMRS of locally Infected and systemfcally infected samples. 


\section{DISCOSSION}

The results from the one way ANOVA did not totally agree with the results reported by Tinnin and Knutson (1980) [Table VIII]. In both studies, a difference between uninfected and heavily infected branches was observed. At S1sters, the mean values for all measured varlables decreased with an increase in branch infection (uninfected to systemic). This shift was found to be significant for all variables with the exception of needle number. At Crescent, all mean values for measured varlables increased wh an increase in branch infection. of the four measured variables, only the values for needle number were found to be statistically different. I suggest that the differences in results between the two sites is a numerical basis for Infected twigs from heavily infected trees at Sisters and lightly Infected trees at Crescent being compared with uninfected twigs. Tinnin and Knutson (1980) reported that heavily Infected branches had longer twigs and more needles than uninfected branches, but there was no significant difference between the combined twig and needle mass of uninfected branches and heavily infected branches.

The differences in reported values is more than 11kely due to the small sample sizes used in both studies. It is also possible that the two host species studied (P1nus contorta in this study, Pseudotsuga menziesil in the Tinnin and Knutson study) are responding differentiy to the presence of Arceuthobium spp. 
COMPARISON OF BRANCH GROWTH CHARACTERISTICS OF PINUS CONTORTA AND PSEUDOTSUGA MENZIESII

\begin{tabular}{|c|c|c|c|}
\hline \multirow[b]{2}{*}{ VARIABLE } & \multicolumn{2}{|c|}{ Pinus contorta } & \multirow{2}{*}{$\frac{\text { Pseudotsuga }}{\text { menzles11* }}$} \\
\hline & SISTERS & CRESCENT & \\
\hline $\begin{array}{l}\text { Twig } \\
\text { Length }\end{array}$ & significant & $\begin{array}{c}\text { not } \\
\text { significant }\end{array}$ & significant \\
\hline $\begin{array}{l}\text { Needle } \\
\text { Number }\end{array}$ & $\begin{array}{c}\text { not } \\
\text { significant }\end{array}$ & significant & significant \\
\hline $\begin{array}{l}\text { Segment } \\
\text { Welght }\end{array}$ & significant & $\begin{array}{c}\text { not } \\
\text { significant }\end{array}$ & $\begin{array}{c}\text { not } \\
\text { significant }\end{array}$ \\
\hline $\begin{array}{l}\text { Average } \\
\text { Needle } \\
\text { Length }\end{array}$ & significant & $\begin{array}{c}\text { not } \\
\text { significant }\end{array}$ & $\begin{array}{c}\text { not } \\
\text { applicable }\end{array}$ \\
\hline
\end{tabular}

* Data from Tinnin and Knutson, 1980. 
The two way nested ANOVA produced mixed results. When this procedure was used to distingulsh branch classification of samples from a g1ven DMR, no cons1stency was observed. The differences between uninfected samples from infected trees and heavily infected samples demonstrated in the one way ANOVA were not observed when only one DMR was analyzed using a two way ANOVA. Similarly, when a two way ANOVA was used to distinguish between DMRs of a single branch classification, the results were mixed. Only locally Infected branches demonstrated any consistency among the measured variables in discriminating between DMRs.

An attempt was made to analyze those sets of data which compared branch classiflcations of DMRs that produced signiflcant results using a Student-Neuman-Ruels test (Sokal and RohIf, 1969). ThIs test would have identifled which branch classifications or DMRs were significantly different. However, due to the amount of variation between the measured varlable means, it was not possible to use this test.

This study was a first attempt to systematically analyze four variables of branch growth. In analyzing the data it was realized that there was too much varlation between samples of one DMR or one branch classification to establish a significant distinction between DMRs or branch classifications. Tables IX and X indicate the sample sizes needed to account for this variation. The sample sizes required are well beyond the scope of this study and will probably prove to be prohibitive to similar research in the future. 
TABLE IX

SAMPLE SIZES NEEDED TO ACCOUNT

FOR OBSERVED VARIATION

AT SISTERS

Uninfected Branches

\begin{tabular}{|l|c|c|}
\hline \multicolumn{1}{|c|}{ VARIABLE } & $\begin{array}{c}\text { LEVEL OF } \\
\text { PRECISION }\end{array}$ & $\begin{array}{c}\text { NEEDED NOMBER } \\
\text { OF SAMPLES }\end{array}$ \\
\hline Tw1g Length & $0.1 \mathrm{~cm}$ & $5.0 \times 10^{4}$ \\
\hline Needle Number & 1.0 needles & 800 \\
\hline Segment Weight & $0.1 \mathrm{~g}$ & $5.0 \times 10^{4}$ \\
\hline $\begin{array}{l}\text { Average Needle } \\
\text { Length }\end{array}$ & $0.1 \mathrm{~cm}$ & $5.0 \times 10^{4}$ \\
\hline
\end{tabular}

Locally Infected Branches

\begin{tabular}{|l|c|c|}
\hline VARIABLE & $\begin{array}{c}\text { LEVEL OF } \\
\text { PRECISION }\end{array}$ & $\begin{array}{c}\text { NEEDED NOMBER } \\
\text { OF SAMPLES }\end{array}$ \\
\hline Twig Length & $0.1 \mathrm{~cm}$ & $1.0 \times 10^{6}$ \\
\hline Needle Number & 1.0 needles & $1.0 \times 10^{4}$ \\
\hline Segment Weight & $0.1 \mathrm{~g}$ & $1.0 \times 10^{6}$ \\
\hline $\begin{array}{l}\text { Average Needle } \\
\text { Length }\end{array}$ & $0.1 \mathrm{~cm}$ & $1.0 \times 10^{6}$ \\
\hline
\end{tabular}


TABLE IX--continued

Systemically Infected Branches

\begin{tabular}{|l|c|c|}
\hline VARIABLE & $\begin{array}{c}\text { LEVEL OF } \\
\text { PRECISION }\end{array}$ & $\begin{array}{c}\text { NEEDED NUMBER } \\
\text { OF SAMPLES }\end{array}$ \\
\hline Tw1g Length & $0.1 \mathrm{~cm}$ & $1.5 \times 10^{6}$ \\
\hline Needle Number & 1.0 needles & $1.5 \times 10^{4}$ \\
\hline Segment Weight & $0.1 \mathrm{~g}$ & $1.5 \times 10^{6}$ \\
\hline $\begin{array}{l}\text { Average Needle } \\
\text { Length }\end{array}$ & $0.1 \mathrm{~cm}$ & $1.5 \times 10^{6}$ \\
\hline
\end{tabular}




\section{TABLE X \\ SAMPLE SIZES NEEDED TO ACCOUNT \\ FOR OBSERVED VARIATION \\ AT CRESCENT}

Uninfected Branches

\begin{tabular}{|l|c|c|}
\hline \multicolumn{1}{|c|}{ VARIABLE } & $\begin{array}{c}\text { LEVEL OF } \\
\text { PRECISION }\end{array}$ & $\begin{array}{c}\text { NEEDED NUMBER } \\
\text { OF SAMPLES }\end{array}$ \\
\hline Twig Length & $0.1 \mathrm{~cm}$ & $5.0 \times 10^{4}$ \\
\hline Needle Number & 1.0 needles & 800 \\
\hline Segment Weight & $0.1 \mathrm{~g}$ & $5.0 \times 10^{4}$ \\
\hline $\begin{array}{l}\text { Average Needle } \\
\text { Length }\end{array}$ & $0.1 \mathrm{~cm}$ & $5.0 \times 10^{4}$ \\
\hline
\end{tabular}

Locally Infected Branches

\begin{tabular}{|l|c|c|}
\hline \multicolumn{1}{|c|}{ VARIABLE } & $\begin{array}{c}\text { LEVEL OF } \\
\text { PRECISION }\end{array}$ & $\begin{array}{c}\text { NEEDED .NUMBER } \\
\text { OF SAMPLES }\end{array}$ \\
\hline Twig Length & $0.1 \mathrm{~cm}$ & $1.5 \times 10^{6}$ \\
\hline Needle Number & 1.0 needles & $2.0 \times 10^{4}$ \\
\hline Segment Weight & $0.1 \mathrm{~g}$ & $1.5 \times 10^{6}$ \\
\hline $\begin{array}{l}\text { Average Needle } \\
\text { Length }\end{array}$ & $0.1 \mathrm{~cm}$ & $1.5 \times 10^{6}$ \\
\hline
\end{tabular}


TABLE X--continued

Systemically Infected Branches

\begin{tabular}{|l|c|c|}
\hline \multicolumn{1}{|c|}{ VARIABLE } & $\begin{array}{c}\text { LRVEL OF } \\
\text { PRECISION }\end{array}$ & $\begin{array}{c}\text { NEEDED NUMBER } \\
\text { OF SAMPLES }\end{array}$ \\
\hline Tw1g Length & $0.1 \mathrm{~cm}$ & $2.0 \times 10^{5}$ \\
\hline Needle Number & 1.0 needles & $3.0 \times 10^{3}$ \\
\hline Segment Welght & 0.18 & $2.5 \times 10^{6}$ \\
\hline $\begin{array}{l}\text { Average. Needle } \\
\text { Length }\end{array}$ & $0.1 \mathrm{~cm}$ & $2.0 \times 10^{5}$ \\
\hline
\end{tabular}


Comparisons of the results from the two way nested ANOVA

were made between overlapping DMRs at the two sites to see if any continuity existed in the response of the host trees to A. americanum at the two sites. DMR 3 and DMR 4 are found in abundance at both sites. Because the results are not consistent between DMR 3 or DMR 4 samples at the two sites, the reported results cannot be interpreted as a general trend for all infected stands of $\underline{p}$ contorta. Again, the reported results may be distorted due to small sample sizes.

The results from both one way ANOVA and two way nested ANOVA Indicate that the dwarf mistletoe rating system devised by Hawksworth (1977) may be too refined to categorize growth response of branches of Pinus contorta Infected with Arceuthobium americanum. The results from one way ANOVA established a difference between the growth of uninfected and heavily infected branches when the dwarf mistletoe rating of the samples is not considered. Conversely, when a single DMR was analyzed, there was no significant difference that consistently appeared between uninfected and heavily infected samples.

Other Investigators have created systems for assessing the extent of dwarf mistletoe Infection to a host tree. Baranyay and Safranyik (1970) used a four class system to differentiate between levels of A. americanum infection in P. contorta. The classes distinguished healthy trees, trees with light branch infection with less than 50 percent of the crown infected, trees with heavy branch and stem Infections with more than 50 percent of the crown Infected, and trees that displayed witches brooms, branch, and stem infections with more than 50 percent of the crown Infected. This type of system may 
be more helpful in assessing the impact of Areuthobium spp. on its host, at least when branch growth of $P_{.}$contorta is considered. The effects of site characteristics on tree growth were not fully addressed in this study. As stated above, the two sites displayed enough differences to require the data from the two sites to be analyzed independently.

Pierce (1960) compared the growth of Infected Douglas fir and larch on varying types of soll. As a result of this study, it was concluded that a decrease in soil quality resulted in a decrease in tree growth.

Baranyay and Safranyik (1970) observed that infected P. contorta growing on dry sites displayed greater changes in growth in response to A. americanum infections than P. contorta growing on wet sites. Rainfall may also be a factor in this study. Crescent recelves a much higher amount of rainfall than Sisters. This varlable, combined with the severity of the Infection at Sisters, may account for the easily detected changes in branch growth between uninfected and heavily infected samples at Sisters. 


\section{CONCLUSIONS}

The preliminary analysis of growth variables conducted by Tinnan and Knutson (1980) was partially confirmed using large samples sizes and the host tree PInus contorta. This confirmation was observed only when the samples were analyzed without regard to the dwarf mistletoe rating of the samples. When the dwarf mistletoe rating is considered, no consistent significant results can be determined between branch classifications or between DMRs when only one branch classification is considered. Too much varlation existed between samples of a given DMR or branch classification to allow for detection of significant differences. The number of samples needed to account for the observed varlation tends to make similar research on this toplc prohibitive.

Further investigations on the effects of site characteristics on Infected tree growth is needed. Such work could account for much, if not most, of the variation observed. 


\section{LITERATURE CITED}

Anonymous. 1975-1979. Climatological Data Annual Summary. National Oceanic and Atmospheric Administration, National Climatic Center Asheville, N. C.

Baranyay, J. 1970. Lodgepole Pine Dwarf Mistletoe in Alberta. Dept. of Fisheries and Forestry. Canadian Forestry Service Publication no. 1286. 22 p.

- and L. Safranyik. 1970. Effect of Dwarf Mistletoe on Growth and Mortality of Lodgepole Pine in Alberta. Dept. of Fisheries and Forestry. Canadian Forestry Service Publication no. 1285. $19 \mathrm{p}$.

Bolsinger, C. 1978. The Extent of Dwarf Mistletoe in Six Principle Softwoods in California, Oregon, and Washington, as Determined from Forest Survey Records. In Proceedings of the Symposium on Dwarf Mistletoe Control Through Forest Management. USDA Forest Service General Technical Report PSW-31. p. 45-54.

Brower, J. and J. Zar. 1977. Field and Laboratory Methods for General Ecology. Wm. C. Brown Co. Dubuque, Iowa. 194 p.

Childs, T. and K. Shea. 1967 Annual Losses from Disease in Pacific Northwest Forests. USDA Forest Service Resource Bulletin PNW-20. $19 \mathrm{p}$.

Gi11, L. and F. Hawksworth, 1964. Dwarf Mistletoe of Lodgepole Pine. USDA Forest Pest Leaflet 18. 7 p.

Hawksworth, F. 1965. Life Tables for Two Species of Dwarf Mistletoe I. Seed Dispersal, Interception, and Movement. For. Sci. $11: 142-151$.

and D. Wiens. 1972. Biology and Classification of Dwarf Mistletoes (Arceuthobium). USDA Agriculture Handbook 401. 234 p.

- 1977. The 6-Class Dwarf Mistletoe Rating System. USDA Forest Service General Technical Report RM-48. 7 p.

Hu11, R. and 0. Leonard. 1964. Physiological Aspects of Parasitism in Mistletoes (Arceuthobium and Phoradendron). II The Photosynthetic Capacity of Mistletoe. Plant Physiology. 39:10081017. 
Johnson, D. W., F. Hawksworth, and D. Drummond. 1980. 1979 Dwarf Mistletoe Loss Assessment Survey on National Forest Lands In Colorado. Report 80-6 Methods Application Group Forest Pest Management. Forest Service-USDA. 18 p.

Miller, J. and R. Tocher. 1975. Photosynthesis and Respiration of Arceuthobium tsugense (Loranthaceae). Am. J. Bot. 62:765-769.

Pierce, William R. 1960. Dwarf Mistletoe and Its Effect Upon the Larch and Douglas Fir of Western Montana. Montana State University Printing Department. 38 p.

Sokal, R. and F. Rohlf. 1969. Blometry. W. H. Freeman and Co., San Francisco. 776 p.

Tinnin, R. and D. Knutson. 1980. Growth Characteristics of the Brooms of Douglas-Fir Caused by Arceuthobium douglasil. For. Sc1. 26:149-158.

Whitehead, D. 1969. Wind Pollination in the Angiosperms: Evolutionary and Environmental Consideration. Evolution 23:28-35. 
APPENDIX A

RESULTS OF TWO WAY ANOVA COMPARING BRANCH CLASSIFICATIONS

OF A GIVEN DMR 
TABLE XI

ANALYSIS OF BRANCH CLASSIFICATIONS FROM PINUS CONTORTA

INFECTED WITH ARCEUTHOBIUM AMERICANOM

AT CRESCENT USING TWO WAY ANOVA

Twig Length

\begin{tabular}{|c|c|c|c|c|c|}
\hline \multicolumn{2}{|c|}{ Source of Variation } & $d f[a]$ & ss [b] & MS [c] & $\mathbf{F}$ \\
\hline \multirow{4}{*}{ DMR } & Among Branch & 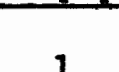 & 131 & 131 & $108[d 1$ \\
\hline & 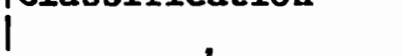 & & & & \\
\hline & Among Treés & 5 & 4.23 & 0.85 & $1.52[d]$ \\
\hline & Among Tree Samples & 13 & 5.55 & 0.43 & \\
\hline \multirow{4}{*}{ DMR } & Among Branch & 1 & 0.89 & 0.89 & $8 \quad 30[07$ \\
\hline & & & & & \\
\hline & Among Trees & 9 & 16.25 & 1.81 & $0.49[d]$ \\
\hline & |Among Tree Samples & 21 & 4.52 & 0.22 & \\
\hline \multirow{3}{*}{ DMR 4} & $\begin{array}{l}\text { Among Branch } \\
\text { Classification }\end{array}$ & 1 & 0.97 & 0.97 & $7.01[\mathrm{e}]$ \\
\hline & Among Trees & 6 & 6.32 & 1.05 & $0.89[d]$ \\
\hline & Among Tree Samples & 15 & 2.25 & 0.15 & \\
\hline
\end{tabular}

[a] - degrees of freedom

[b] - sum of squares

[c] - mean squares

[d] - not significant

[e] - significant at 0.05 
TABLE XII

ANALYSIS OF BRANCH CLASSIFICATIONS FROM PINUS CONTORTA

INFECTED WITH ARCEUTHOBIUM AMERICANUM

AT SISTERS USING TWO WAY ANOVA

Tw1g Length

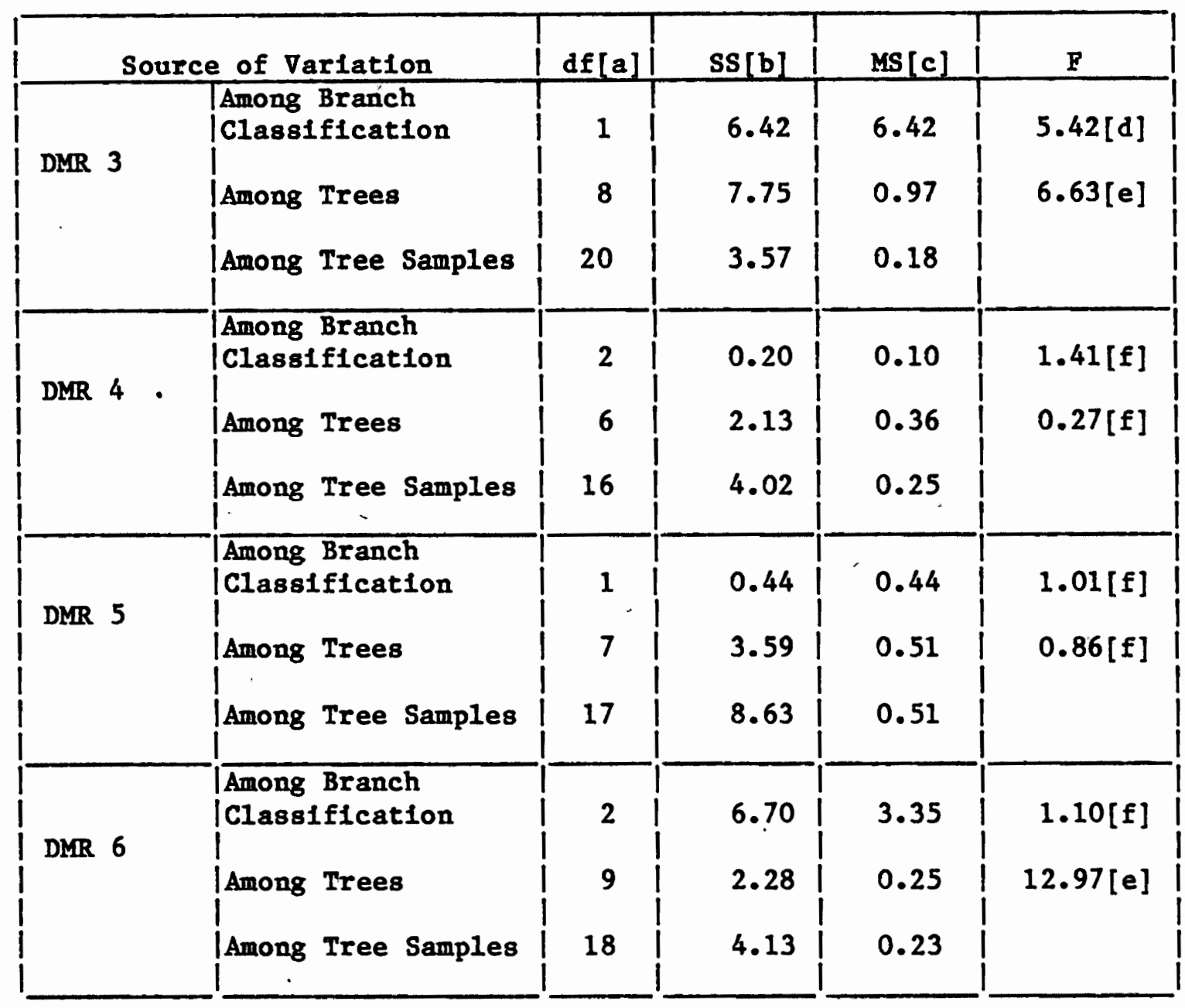

[a] - degrees of freedom

[b] - sum of squares

[c] - mean squares

[d] - significant at 0.05

[e] - significant at 0.01

[f] - not significant 
TABLE XIII

ANALYSIS OF BRANCH CLASSIFICATIONS FROM PINUS CONTORTA

INFECTED WITH ARCEUTHOBIUM AMERICANUM

AT CRESCENT USING TWO WAY ANOVA

Needle Number

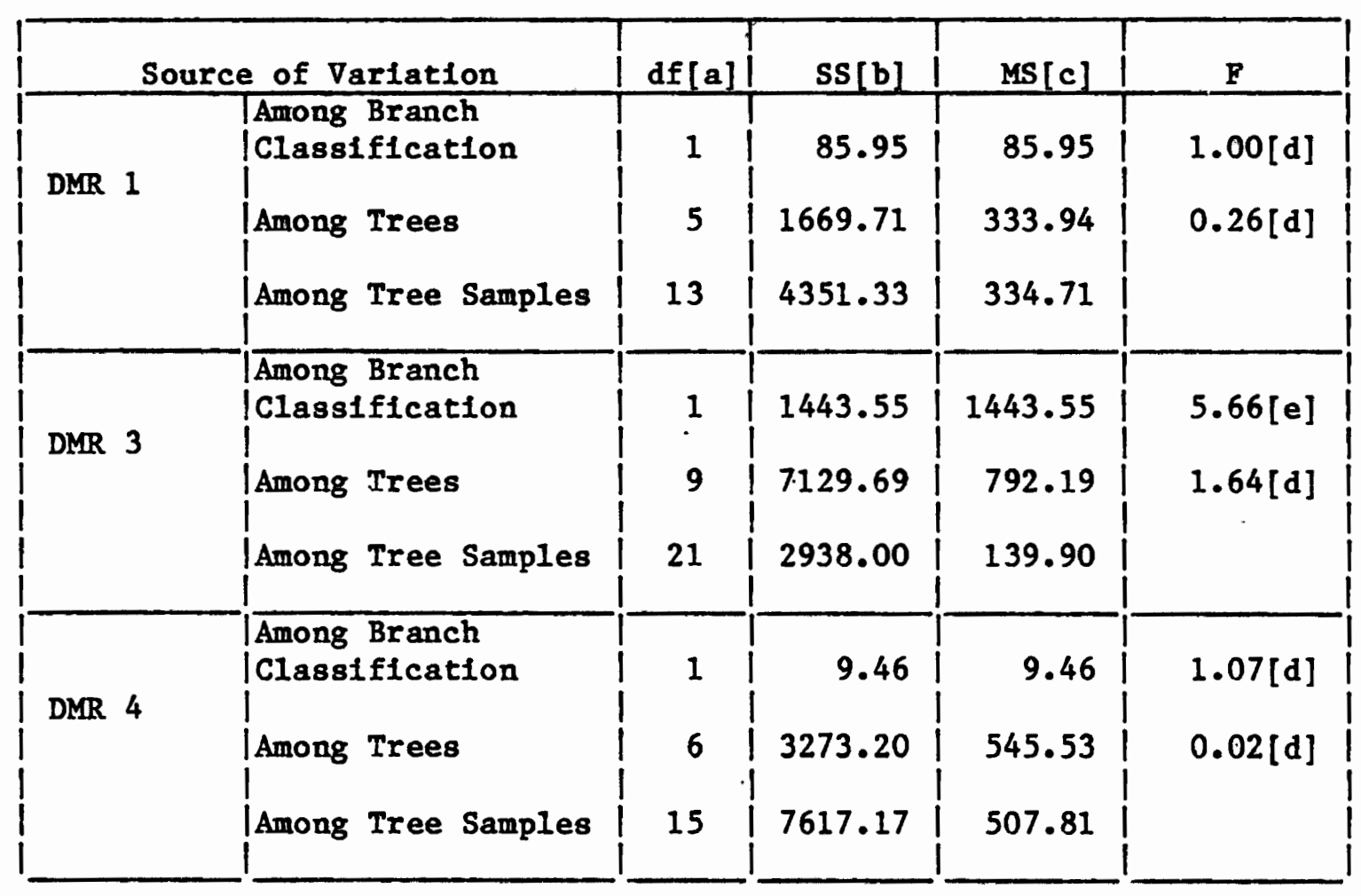

[a] - degrees of freedom

[b] - sum of squares

[c] - mean squares

[d] - not significant

[e] - significant at 0.05 


\title{
TABLE XIV
}

\begin{abstract}
ANALYSIS OF BRANCH CLASSIFICATIONS FROM PINUS CONTORTA INFECTED WITH ARCEUTHOBIUM AMERICANUM AT SISTERS USING TWO WA $\bar{Y}$ ANOVA
\end{abstract}

Needle Number

\begin{tabular}{|c|c|c|c|c|c|}
\hline \multicolumn{2}{|c|}{ Source of Variation } & $d f[a]$ & sS [b] & MS [c] & $\mathbf{F}$ \\
\hline \multirow{4}{*}{ DMR } & Among Branch & & & & \\
\hline & |Classification & 1 & 13.14 & 13.14 & $0.61[d]$ \\
\hline & Among Trees & 8 & 1944.89 & 243.11 & $0.05[\mathrm{~d}]$ \\
\hline & Among Tree Samples & 20 & 7923.33 & 396.17 & \\
\hline \multirow{4}{*}{ DMR 4} & Among Branch & 2 & 1308,44 & 654.22 & 6.28101 \\
\hline & & & & & \\
\hline & Among Trees & 6 & 5781.56 & 963.59 & $0.67[\mathrm{~d}]$ \\
\hline & |Among Tree Samples & 16 & 2454.67 & 153.42 & \\
\hline \multirow{3}{*}{ DMR 5} & $\begin{array}{l}\text { Among Branch } \\
\text { |Classification }\end{array}$ & 1 & 198.86 & 198.86 & $1.05[\mathrm{~d}]$ \\
\hline & Among Trees & 7 & 1701.69 & 243.10 & $0.82[d]$ \\
\hline & Among Tree Samples & 17 & 3941.33 & 231.84 & \\
\hline \multirow{3}{*}{ DMR 6} & $\begin{array}{l}\text { Among Branch } \\
\text { Classification }\end{array}$ & 2 & 9793.30 & 4896.65 & $2.51[\mathrm{~d}]$ \\
\hline & Among Trees & 9 & 3211.67 & 356.85 & $12.00[\mathrm{f}]$ \\
\hline & Among Tree Samples & 18 & 2554.50 & 141.93 & \\
\hline
\end{tabular}
[a] - degrees of freedom
[b] - sum of squares
[c] - mean squares
[d] - not significant
[e] - significant at 0.05
[f] - significant at 0.01 
TABLE XV

ANALYSIS OF BRANCH CLASSIFICATIONS FROM PINUS CONTORTA INFECTED WITH ARCEUTHOBIUM AMERI $\overline{\text { CANUM }}$ AT CRESCENT USING TWO WAY ANOVA

Total Segment Weight

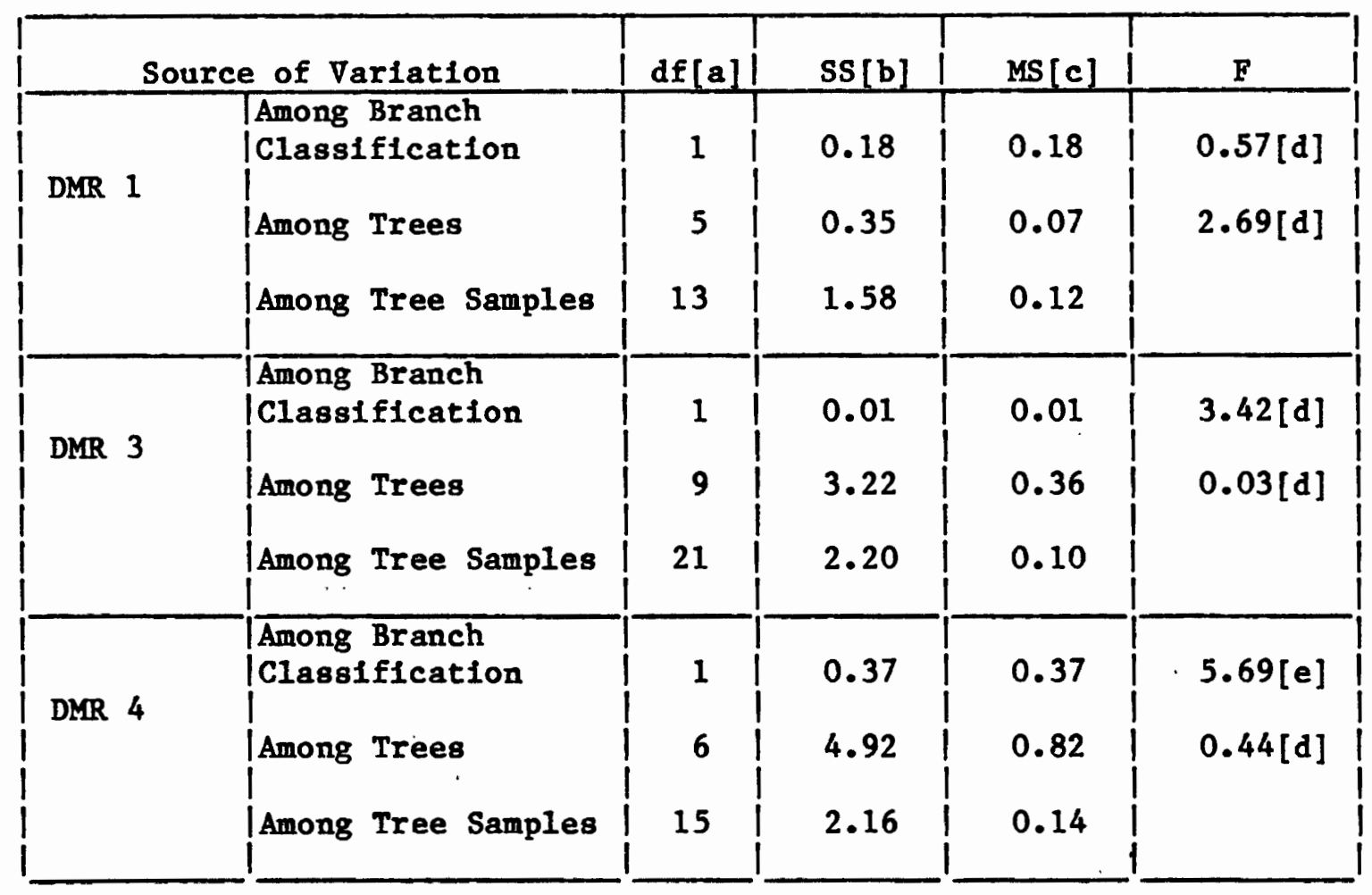
[a] - degrees of freedom
[b] - sum of squares
[c] - mean squares
[d] - not significant
[e] - significant at 0.05 
TABLE XVI

ANALYSIS OP BRANCH CLASSIFICATIONS FROM PINUS CONTORTA INPECTED WITH ARCEUTHOBIUM AMERICANUM AT SISTERS USING TWO WAY ANOVA

Total Segment Welght

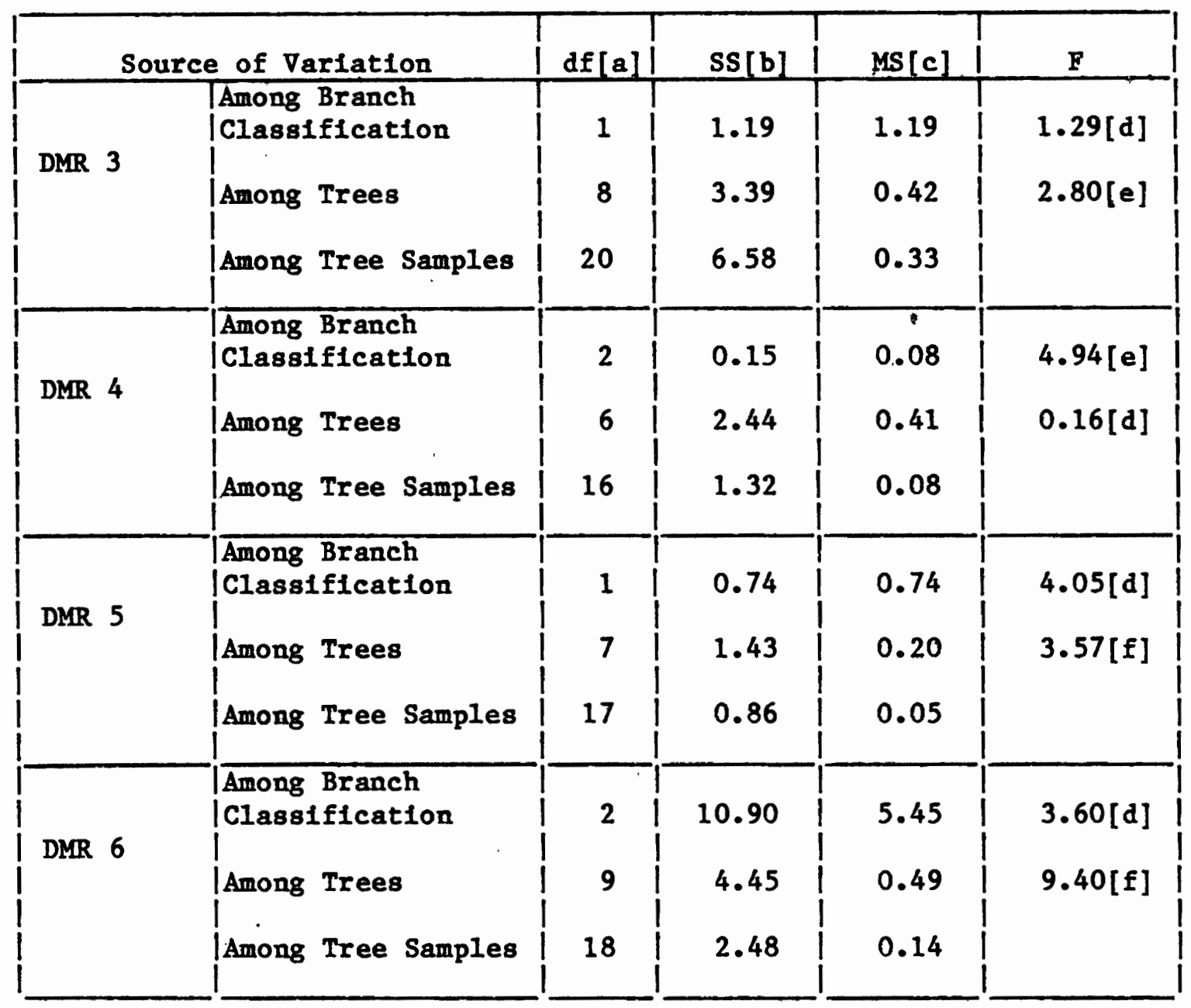

[a] - degrees of freedom

[b] - sum of squares

[c] - mean squares

[d] - not significant

[e] - significant at 0.05

[f] - significant at 0.01 
TABLE XVII

ANALYSIS OF BRANCH CLASSIFICATIONS FROM PINOS CONTORTA INFECTED WITH ARCEUTHOBIUM AMERICANUM AT CRESCENT USING TWO WAY ANOVA

Average Needle Length

\begin{tabular}{|c|c|c|c|c|c|}
\hline \multicolumn{2}{|c|}{ Source of Varlation } & $\operatorname{df}[a]$ & ss[b] & MS [c] & $\mathbf{F}$ \\
\hline DMR 1 & $\begin{array}{l}\text { Among Branch } \\
\text { Classification } \\
\text { Among Trees } \\
\text { Among Tree Samples }\end{array}$ & $\begin{array}{r}1 \\
5 \\
13\end{array}$ & $\begin{array}{r}1.52 \\
13.35 \\
4.30\end{array}$ & $\begin{array}{l}1.52 \\
2.67 \\
0.33\end{array}$ & $\begin{array}{l}8.70[d] \\
0.55[e]\end{array}$ \\
\hline DMR 3 & $\begin{array}{l}\text { Among Branch } \\
\text { Classification } \\
\text { Among Trees } \\
\text { Among Tree Samples }\end{array}$ & $\begin{array}{r}1 \\
9 \\
21\end{array}$ & $\begin{array}{r}0.19 \\
11.23 \\
7.15\end{array}$ & $\begin{array}{l}0.19 \\
1.25 \\
0.34\end{array}$ & $\begin{array}{l}3.67[e] \\
0.15[e]\end{array}$ \\
\hline DMR 4 & $\begin{array}{l}\text { Among Branch } \\
\text { |Classification } \\
\text { Among Trees } \\
\text { Among Tree Samples }\end{array}$ & $\begin{array}{r}1 \\
6 \\
15\end{array}$ & $\begin{array}{l}0.86 \\
7.96 \\
4.49\end{array}$ & $\begin{array}{l}0.86 \\
1.32 \\
0.30\end{array}$ & $\begin{array}{l}4.41[e] \\
0.63[e]\end{array}$ \\
\hline
\end{tabular}
[a] - degrees of freedom
[b] - sum of squares
[c] - mean squares
[d] - significant at 0.05
[e] - not significant 
TABLE XVIII

ANALYSIS OF BRANCH CLASSIFICATIONS PROM PINOS CONTORTA

INFECTED WITH ARCEUTHOBIUM AMERI CANUM

AT SISTERS USING TWO WAT ANOVA

Average Needle Length

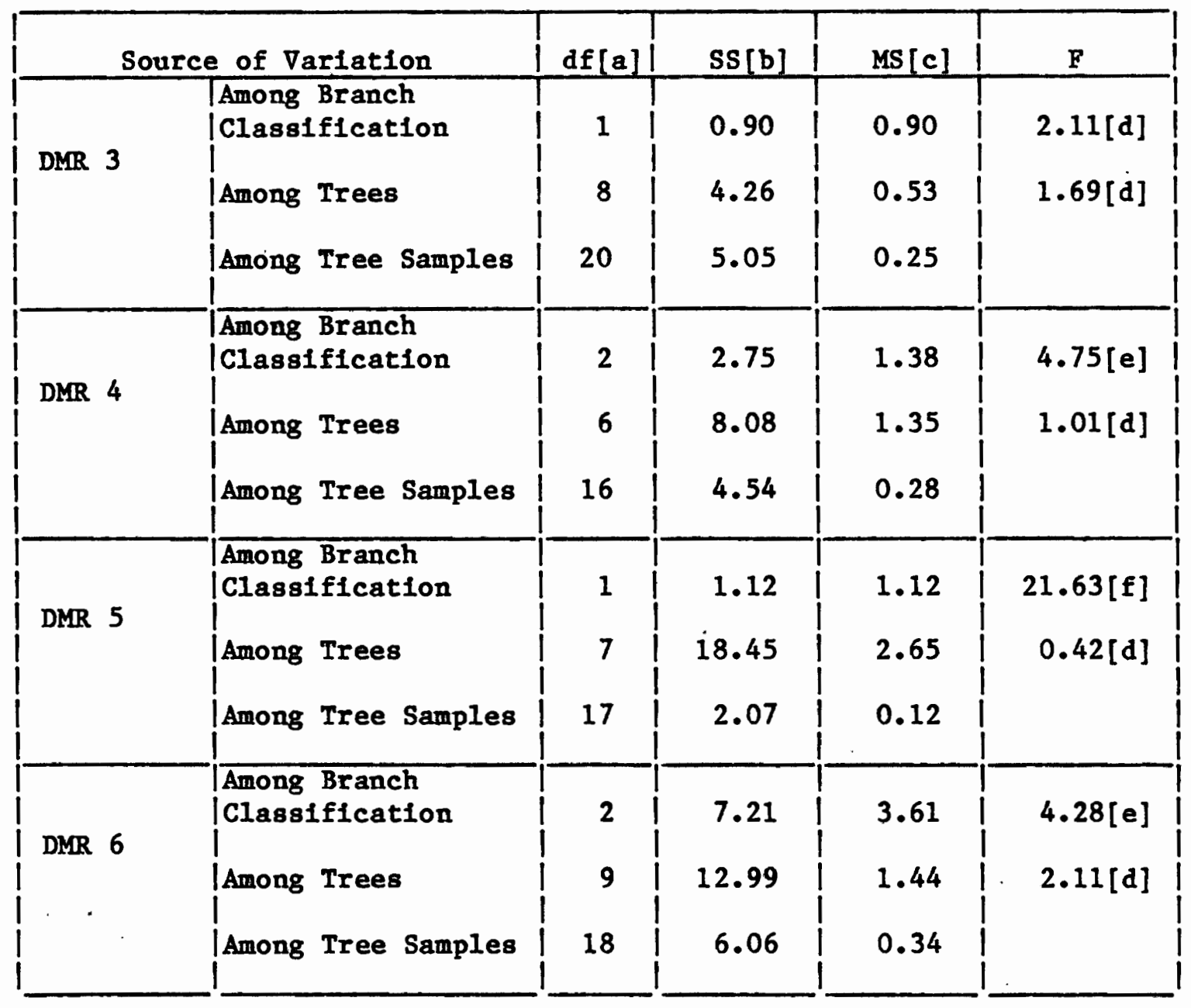

[a] - degrees of freedom

[b] - sum of squares

[c] - mean squares

[d] - not significant

[e] - significant at 0.05

[f] - significant at 0.01 
APPENDIX B

RESULTS OF TWO WAY ANOVA COMPARING

INPECTION LEVELS OF A GIVEN

BRANCH CLASSIFICATION 
TABLE XIX

ANALYSIS OF INFECTION LEVELS OF PINUS CONTORTA INFECTED WITH ARCEUTHOBIUM AMERICANOM AT CRESCENT USING TWO WAY ANOVA

Twig Length

\begin{tabular}{|c|c|c|c|c|c|}
\hline Sourc & e of Variation & $d f[a]$ & ss [b] & $\mathrm{MS}[\mathrm{c}]$ & $\mathbf{F}$ \\
\hline Oninfected & $\mid \begin{array}{l}\text { Among DMRs } \\
\text { Among Trees } \\
\text { Among Tree Samples }\end{array}$ & $\begin{array}{c}1 \\
3 \\
10\end{array}$ & $\begin{array}{l}0.24 \\
3.98 \\
5.85\end{array}$ & $\begin{array}{l}0.24 \\
1.33 \\
0.58\end{array}$ & $\begin{array}{l}2.27[d] \\
0.18[d]\end{array}$ \\
\hline Local & $\begin{array}{l}\text { Among DMRs } \\
\text { Among Trees } \\
\text { Among Tree Samples }\end{array}$ & $\begin{array}{r}4 \\
18 \\
43\end{array}$ & $\begin{array}{r}6.17 \\
19.75 \\
7.39\end{array}$ & $\begin{array}{l}1.54 \\
1.10 \\
0.17\end{array}$ & $\begin{array}{l}6.39[\mathrm{e}] \\
1.43[\mathrm{~d}]\end{array}$ \\
\hline Systemic & $\mid \begin{array}{l}\text { Among DMRs } \\
\text { Among Trees } \\
\text { Among Tree Samples }\end{array}$ & $\begin{array}{r}2 \\
6 \\
16\end{array}$ & $\begin{array}{l}1.61 \\
7.93 \\
4.52\end{array}$ & $\begin{array}{l}0.81 \\
1.32 \\
0.28\end{array}$ & $\begin{array}{l}4.68[d] \\
0.68[d]\end{array}$ \\
\hline
\end{tabular}
[a] - degrees of freedom
[b] - sum of squares
[c] - mean squares
[d] - not significant
[e] - significant at 0.01 
TABLE XX

ANALYSIS OF INFECTION LEVELS OF PINUS CONTORTA INFECTED WITH ARCEUTHOBIUM AMERICANOM AT SISTERS USING TWO WAY ANOVA

Twig Length

\begin{tabular}{|c|c|c|c|c|c|}
\hline Soure & $e$ of Variation & $\operatorname{df}[a]$ & SS[b] & MS [c] & $\mathbf{F}$ \\
\hline Uninfected & $\begin{array}{l}\text { Among DMRs } \\
\text { Among Trees } \\
\text { Among Tree Samples }\end{array}$ & $\begin{array}{r}2 \\
2 \\
10\end{array}$ & $\begin{array}{l}3.80 \\
2.43 \\
1.45\end{array}$ & $\begin{array}{l}1.90 \\
1.21 \\
0.14\end{array}$ & $\begin{array}{l}8.39[d] \\
1.57[d]\end{array}$ \\
\hline Local & $\begin{array}{l}\text { Among DMRs } \\
\text { Among Trees } \\
\text { Among Tree Samples }\end{array}$ & $\begin{array}{r}3 \\
15 \\
35\end{array}$ & $\begin{array}{r}6.18 \\
8.95 \\
10.85\end{array}$ & $\begin{array}{l}2.06 \\
0.60 \\
0.31\end{array}$ & $\begin{array}{l}1.92[d] \\
3.38[e]\end{array}$ \\
\hline Systemic & $\begin{array}{l}\text { Among DMRs } \\
\text { Among Trees } \\
\text { Among Tree Samples }\end{array}$ & $\begin{array}{r}3 \\
20 \\
39\end{array}$ & $\begin{array}{r}5.27 \\
26.98 \\
8.35\end{array}$ & $\begin{array}{l}1.76 \\
1.35 \\
0.21\end{array}$ & $\begin{array}{l}6.30[\mathrm{e}] \\
1.18[\mathrm{~d}]\end{array}$ \\
\hline
\end{tabular}
[a] - degrees of freedom
[b] - sum of squares
[c] - mean squares
[d] - not significant
[e] - significant at 0.01 
TABLE XXI

ANALYSIS OF INFECTION LEVELS OF PINES CONTORTA INFECTED WITH ARCEUTHOBIUM AMERICANOM AT CRESCENT USING TWO WAY ANOVA

Needle Number

\begin{tabular}{|c|c|c|c|c|c|}
\hline Sourc & e of Variation & $d f[a]$ & ss [b] & MS [c] & $\mathbf{F}$ \\
\hline Uninfected & $\begin{array}{l}\text { Among DMRs } \\
\text { Among Trees } \\
\text { Among Tree Samples }\end{array}$ & $\begin{array}{r}1 \\
3 \\
10\end{array}$ & $\begin{array}{r}683.38 \\
256.22 \\
2829.33\end{array}$ & $\begin{array}{r}683.38 \\
85.41 \\
282.93\end{array}$ & $\begin{array}{l}0.03[d] \\
8.00[e]\end{array}$ \\
\hline Local & $\begin{array}{l}\text { Among DMRs } \\
\text { Among Trees } \\
\text { Among Tree Samples }\end{array}$ & $\begin{array}{r}4 \\
18 \\
43\end{array}$ & $\begin{array}{r}3137.05 \\
17390.93 \\
10037.83\end{array}$ & $\begin{array}{l}784.26 \\
966.16 \\
233.44\end{array}$ & $\begin{array}{l}4.14[e] \\
0.83[d]\end{array}$ \\
\hline Systemic & $\begin{array}{l}\text { Among DMRs } \\
\text { Among Trees } \\
\text { Among Tree Samples }\end{array}$ & $\begin{array}{r}2 \\
6 \\
16\end{array}$ & $\begin{array}{r}73.79 \\
2891.88 \\
5006.33\end{array}$ & $\begin{array}{r}36.89 \\
481.98 \\
312.90\end{array}$ & $\begin{array}{l}1.54[d] \\
0.08 \text { [d] }\end{array}$ \\
\hline
\end{tabular}
[a] - degrees of freedom
[b] - sum of squares
[c] - mean squares
[d] - not significant
[e] - significant at 0.01 
TABLE XXII

ANALYSIS OF INFECTION LEVELS OF PINUS CONTORTA

INFECTED WITH ARCEUTHOBIUM AMERICANUM AT SISTERS OSING TWO WAY ANOVA

Needle Number

\begin{tabular}{|c|c|c|c|c|c|}
\hline Sourc & $e$ of Variation & $\mathrm{df}[\mathrm{a}]$ & SS [b] & $\operatorname{MS}[c]$ & F \\
\hline Oninfected & $\begin{array}{l}\text { Among DMRs } \\
\text { Among Trees } \\
\text { Among Tree Samples }\end{array}$ & $\begin{array}{r}2 \\
2 \\
10\end{array}$ & $\begin{array}{r}11921.38 \\
254.89 \\
5739.33\end{array}$ & $\begin{array}{r}5960.69 \\
127.44 \\
573.93\end{array}$ & $\begin{array}{l}0.22[\mathrm{~d}] \\
46.77[\mathrm{e}]\end{array}$ \\
\hline Local & $\begin{array}{l}\text { Among DMRs } \\
\text { Among Trees } \\
\text { Among Tree Samples }\end{array}$ & $\begin{array}{r}3 \\
15 \\
35\end{array}$ & $\begin{array}{r}704.19 \\
7973.51 \\
5276.67\end{array}$ & $\begin{array}{l}234.73 \\
531.57 \\
150.76\end{array}$ & $\begin{array}{l}3.53[\mathrm{f}] \\
0.43[\mathrm{~d}]\end{array}$ \\
\hline Systemic & $\begin{array}{l}\text { Among DMRs } \\
\text { Among Trees } \\
\text { Among Tree Samples }\end{array}$ & $\begin{array}{r}3 \\
20 \\
39\end{array}$ & $\begin{array}{l}2210.71 \\
6460.29 \\
8871.00\end{array}$ & $\begin{array}{l}736.90 \\
323.01 \\
227.46\end{array}$ & $\begin{array}{l}1.42[d] \\
2.20[f]\end{array}$ \\
\hline
\end{tabular}

[a] - degrees of freedom

[b] - sum of squares

[c] - mean squares

[d] - not significant

[e] - significant at 0.01

[f] - significant at 0.05 


\section{TABLE XXIII}

ANALYSIS OF INFECTION LEVELS OF PINUS CONTORTA INPECTED WITH ARCEUTHOBIUM AMERICANUM AT CRESCENT USING TWO WAY ANOVA

Total Segment Welght

\begin{tabular}{|c|c|c|c|c|c|}
\hline Sourc & of Variation & $d f[a]$ & SS [b] & $\operatorname{MS}[c]$ & $\underline{F}$ \\
\hline Uninfected & $\begin{array}{l}\text { Among DMRs } \\
\text { Among Trees } \\
\text { Among Tree Samples }\end{array}$ & $\begin{array}{r}1 \\
3 \\
10\end{array}$ & $\begin{array}{l}0.02 \\
0.54 \\
1.57\end{array}$ & $\begin{array}{l}0.02 \\
0.18 \\
0.16\end{array}$ & $\begin{array}{l}1.13[d] \\
0.11[d]\end{array}$ \\
\hline Local & $\begin{array}{l}\text { Among DMRs } \\
\text { Among Trees } \\
\text { Among Tree Samples }\end{array}$ & $\begin{array}{r}4 \\
18 \\
43\end{array}$ & $\begin{array}{l}2.62 \\
9.08 \\
5.62\end{array}$ & $\begin{array}{l}0.66 \\
0.50 \\
0.13\end{array}$ & $\begin{array}{l}3.86[e] \\
1.32[d]\end{array}$ \\
\hline Systemic & $\begin{array}{l}\text { Among DMRs } \\
\text { Among Trees } \\
\text { Among Tree Samples }\end{array}$ & $\begin{array}{r}2 \\
6 \\
16\end{array}$ & $\begin{array}{l}0.25 \\
3.45 \\
3.58\end{array}$ & $\begin{array}{l}0.13 \\
0.57 \\
0.22\end{array}$ & $\begin{array}{l}2.57[d] \\
0.24[d]\end{array}$ \\
\hline
\end{tabular}

[a] - degrees of freedom

[b] - sum of squares

[c] - mean squares

[d] - not significant

[e] - significant at 0.05 
TABLE XXIV

ANALYSIS OF INFECTION LEVELS OF PINOS CONTORTA

INFECTED WITH ARCEUTHOBIOM AMERICANUM

AT SISTERS USING TWO WAY ANOVA

Total Segment Welght

\begin{tabular}{|c|c|c|c|c|c|}
\hline Sourc & e of Variation & $\mathrm{df}[\mathrm{a}]$ & ss [b] & MS [c] & $\mathbf{F}$ \\
\hline Uninfected & $\begin{array}{l}\text { Among DMRs } \\
\text { Among Trees } \\
\text { Among Tree Samples }\end{array}$ & $\begin{array}{r}2 \\
2 \\
10\end{array}$ & $\begin{array}{l}8.25 \\
0.42 \\
5.27\end{array}$ & $\begin{array}{l}4.12 \\
0.21 \\
0.53\end{array}$ & $\begin{array}{c}0.40[\mathrm{~d}] \\
19.46[\mathrm{e}]\end{array}$ \\
\hline Local & $\begin{array}{l}\text { Among DMRs } \\
\text { Among Trees } \\
\text { Among Tree Samples }\end{array}$ & $\begin{array}{r}3 \\
15 \\
35\end{array}$ & $\begin{array}{l}8.8 \times 10^{8} \\
4.5 \times 10^{9} \\
7.5 \times 10^{9}\end{array}$ & $\begin{array}{l}2.9 \times 10^{8} \\
3.0 \times 10^{8} \\
2.1 \times 10^{8}\end{array}$ & $\begin{array}{l}1.41[d] \\
0.96[d]\end{array}$ \\
\hline Systemlc & $\begin{array}{l}\text { |Among DMRs } \\
\text { |Among Trees } \\
\text { Among Tree Samples }\end{array}$ & $\begin{array}{r}3 \\
20 \\
39\end{array}$ & $\begin{array}{l}0.24 \\
5.52 \\
4.47\end{array}$ & $\begin{array}{l}0.08 \\
0.28 \\
0.11\end{array}$ & $\begin{array}{l}2.41[d] \\
0.27[d]\end{array}$ \\
\hline
\end{tabular}

[a] - degrees of freedom

[b] - sum of squares

[c] - mean squares

[d] - not significant

[e] - significant at 0.01 
TABLE XXV

ANALYSIS OF INFECTION LEVELS OF PINUS CONTORTA INFECTED WITH ARCEUTHOBIUM AMRRICANUM

AT CRESCENT US ING TWO WAY ANOVA

Average Needle Length

\begin{tabular}{|c|c|c|c|c|c|}
\hline Source & of Variation & $\operatorname{df}[a]$ & SS [b] & MS [c] & $\mathrm{F}$ \\
\hline \multirow{3}{*}{ Uninfected } & Among DMRs & 1 & 1.13 & 1.13 & $5.60[d]$ \\
\hline & Among Trees & 3 & 0.06 & 3.02 & 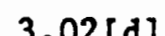 \\
\hline & Among Tree Samples & 10 & 5.39 & 0.54 & \\
\hline \multirow{3}{*}{ Local } & Among DMRs & 4 & 7.47 & 1.87 & $5.89[\mathrm{e}]$ \\
\hline & Among Trees & 18 & 33.57 & 1.87 & $1.02[\mathrm{~d}]$ \\
\hline & Among Tree Samples & 43 & 13.61 & 0.32 & \\
\hline \multirow{3}{*}{ Systemic. } & Among DMRs & 2 & 0.26 & 0.13 & $4.60[d]$ \\
\hline & Among Trees & 6 & 5.98 & 1.00 & $0.15[\mathrm{~d}]$ \\
\hline & Among Tree Samples & 16 & 3.47 & 0.22 & \\
\hline
\end{tabular}

[a] - degrees of freedom

[b] - sum of squares

[c] - mean squares

[d] - not significant

[e] - significant at 0.01 
TABLE XXVI

ANALYSIS OF INFECTION LEVELS OF PINUS CONTORTA

INFECTED WITH ARCEUTHOBIUM AMERICANOM

AT SISTERS USING TWO WAY ANOVA

Average Needle Length

\begin{tabular}{|c|c|c|c|c|c|}
\hline Sourc & $e$ of Variation & $\mathrm{df}[\mathrm{a}]$ & SS [b] & $\operatorname{MS}[c]$ & $\mathbf{F}$ \\
\hline Uninfected & $\begin{array}{l}\text { Among DMRs } \\
\text { Among Trees } \\
\text { Among Tree Samples }\end{array}$ & $\begin{array}{r}2 \\
2 \\
10\end{array}$ & $\begin{array}{l}3.95 \\
1.24 \\
3.43\end{array}$ & $\begin{array}{l}1.97 \\
0.62 \\
0.34\end{array}$ & $\begin{array}{l}1.80[d] \\
3.20[d]\end{array}$ \\
\hline Local & $\begin{array}{l}\text { Among DMRs } \\
\text { Among Trees } \\
\text { Among Tree Samples }\end{array}$ & $\begin{array}{r}3 \\
15 \\
35\end{array}$ & $\begin{array}{r}0.03 \\
30.70 \\
21.29\end{array}$ & $\begin{array}{l}0.01 \\
2.05 \\
0.61\end{array}$ & $\begin{array}{l}3.36[e] \\
0.01[d]\end{array}$ \\
\hline Systemic & \begin{tabular}{|l}
$\mid$ Among DMRs \\
Among Trees \\
Among Tree Samples
\end{tabular} & $\begin{array}{r}3 \\
20 \\
39\end{array}$ & $\begin{array}{r}1.81 \\
21.39 \\
9.88\end{array}$ & $\begin{array}{l}0.60 \\
1.07 \\
0.25\end{array}$ & $\begin{array}{l}4.22[e] \\
0.52[d]\end{array}$ \\
\hline
\end{tabular}

[a] - degrees of freedom

[b] - sum of squares

[c] - mean squares

[d] - not significant

[e] - significant at 0.05 
APPENDIX C

MEAN VALUES FOR MEASURED VARIABLES 
TABLE XXVII

MEAN VALUES FOR MEASURED VARIABLES AT CRESCENT

Twig Length

\begin{tabular}{|c|c|c|c|}
\hline DMR & UNINFECTED & LOCAL & SYSTEMIC \\
\hline 0 & $2.1 \pm 0.19$ & - & - \\
\hline 1 & $2.3 \pm 0.50$ & $1.7 \pm 0.11$ & - \\
\hline 2 & - & $3.8 \pm 0.13$ & - \\
\hline 3 & - & $2.3 \pm 0.22$ & $2.5 \pm 0.19$ \\
\hline 4 & - & $3.4 \pm 0.12$ & $2.1 \pm 0.30$ \\
\hline 5 & - & $2.5 \pm 0.31$ & $2.9 \pm 0.35$ \\
\hline
\end{tabular}

Needle Number

\begin{tabular}{|c|c|c|c|}
\hline DMR & UNINFECTED & LOCAL & SYSTEMIC \\
\hline 0 & $49 \pm 3.5$ & - & - \\
\hline 1 & $41 \pm 5.2$ & $36 \pm 4.6$ & - \\
\hline 2 & - & $58 \pm 4.0$ & - \\
\hline 3 & - & $51 \pm 5.4$ & $61 \pm 5.1$ \\
\hline 4 & - & $47 \pm 5.6$ & $60 \pm 8.0$ \\
\hline 5 & - & $47 \pm 10.5$ & $57 \pm 13.5$ \\
\hline
\end{tabular}


TABLE XXVII--continued

Total Segment Weight

\begin{tabular}{|c|c|c|c|}
\hline DMR & UNINFECTED & LOCAL & SYSTEMIC \\
\hline 0 & $\begin{array}{l}0.7831 \pm \\
0.12\end{array}$ & - & - \\
\hline 1 & $\begin{array}{l}0.7080 \pm \\
0.19\end{array}$ & $\begin{array}{l}0.5015 \pm \\
0.07\end{array}$ & - \\
\hline 2 & - & $\begin{array}{l}1.0795 \pm \\
0.12\end{array}$ & - \\
\hline 3 & - & $\begin{array}{l}0.8241 \pm \\
0.11\end{array}$ & $\begin{array}{l}0.8701 \pm \\
0.09\end{array}$ \\
\hline 4 & - & $\begin{array}{l}0.6973 \pm \\
0.10\end{array}$ & $\begin{array}{l}1.0479 \pm \\
0.26\end{array}$ \\
\hline 5 & - & $\begin{array}{l}1.0012 \pm \\
0.32\end{array}$ & $\begin{array}{l}1.1294 \pm \\
0.23\end{array}$ \\
\hline
\end{tabular}

Average Needle Length

\begin{tabular}{|c|c|c|c|}
\hline DMR & UNINFECTED & LOCAL & SYSTEMIC \\
\hline 0 & $3.4 \pm 0.31$ & - & - \\
\hline 1 & $3.9 \pm 0.51$ & $3.3 \pm 0.24$ & - \\
\hline 2 & - & $4.0 \pm 0.20$ & - \\
\hline 3 & - & $3.4 \pm 0.23$ & $3.6 \pm 0.17$ \\
\hline 4 & - & $3.7 \pm 0.21$ & $3.8 \pm 0.27$ \\
\hline 5 & - & $4.4 \pm 0.41$ & $3.8 \pm 0.15$ \\
\hline
\end{tabular}


TABLE XXVIII

MEAN VALUES FOR MEASURED VARIABLES AT SISTERS

Tw1g Length

\begin{tabular}{|c|c|c|c|}
\hline DMR & UNINFECIED & LOCAL & SYSTEMIC \\
\hline 3 & $2.7 \pm 0.22$ & $2.5 \pm 0.13$ & $1.7 \pm 0.03$ \\
\hline 4 & $1.8 \pm 0.12$ & $1.9 \pm 0.15$ & $2.4 \pm 0.33$ \\
\hline 5 & - & $2.4 \pm 0.21$ & $2.0 \pm 0.12$ \\
\hline 6 & $3.3 \pm 0.20$ & $1.7 \pm 0.12$ & $1.8 \pm 0.97$ \\
\hline
\end{tabular}

Needle Number

\begin{tabular}{|c|c|c|c|}
\hline DMR & UNINFECTED & LOCAL & SYSTEMIC \\
\hline 3 & $53 \pm 9.1$ & $52 \pm 2.9$ & $30 \pm 5.3$ \\
\hline 4 & $32 \pm 1.2$ & $55 \pm 5.7$ & $59 \pm 3.7$ \\
\hline 5 & - & $61 \pm 3.5$ & $52 \pm 3.5$ \\
\hline 6 & $115 \pm 1.3$ & $56 \pm 6.6$ & $55 \pm 3.3$ \\
\hline
\end{tabular}


TABLE XXVIII--continued

Total Segment Welght.

\begin{tabular}{|c|c|c|c|}
\hline DMR & UNINFECTED & LOCAL & SYSTEMIC \\
\hline 3 & $\begin{array}{l}1.2430 \pm \\
0.28\end{array}$ & $\begin{array}{l}0.7133 \pm \\
0.09\end{array}$ & $\begin{array}{l}0.5787 \pm \\
0.10\end{array}$ \\
\hline 4 & $\begin{array}{l}0.5804 \pm \\
0.05\end{array}$ & $\begin{array}{l}0.8005 \pm \\
0.13\end{array}$ & $\begin{array}{l}0.8053 \pm \\
0.05\end{array}$ \\
\hline 5 & - & $\begin{array}{l}0.9802 \pm \\
0.09\end{array}$ & $\begin{array}{l}0.7405 \pm \\
0.06\end{array}$ \\
\hline 6 & $\begin{array}{l}2.8162 \pm \\
0.04\end{array}$ & $\begin{array}{l}0.7117 \pm \\
0.07\end{array}$ & $\begin{array}{l}0.8439 \pm \\
0.13\end{array}$ \\
\hline
\end{tabular}

Average Needle Length

\begin{tabular}{|c|c|c|c|}
\hline DMR & UNINFECTED & LOCAL & SYSTEMIC \\
\hline 3 & $3.8 \pm 0.24$ & $3.4 \pm 0.11$ & $4.0 \pm 0.35$ \\
\hline 4 & $3.3 \pm 0.29$ & $3.3 \pm 0.22$ & $3.5 \pm 0.18$ \\
\hline 5 & - & $3.8 \pm 0.29$ & $3.4 \pm 0.10$ \\
\hline 6 & $4.9 \pm 0.01$ & $3.3 \pm 0.24$ & $3.3 \pm 0.20$ \\
\hline
\end{tabular}


APPENDIX D

SAMPLE SIZES 


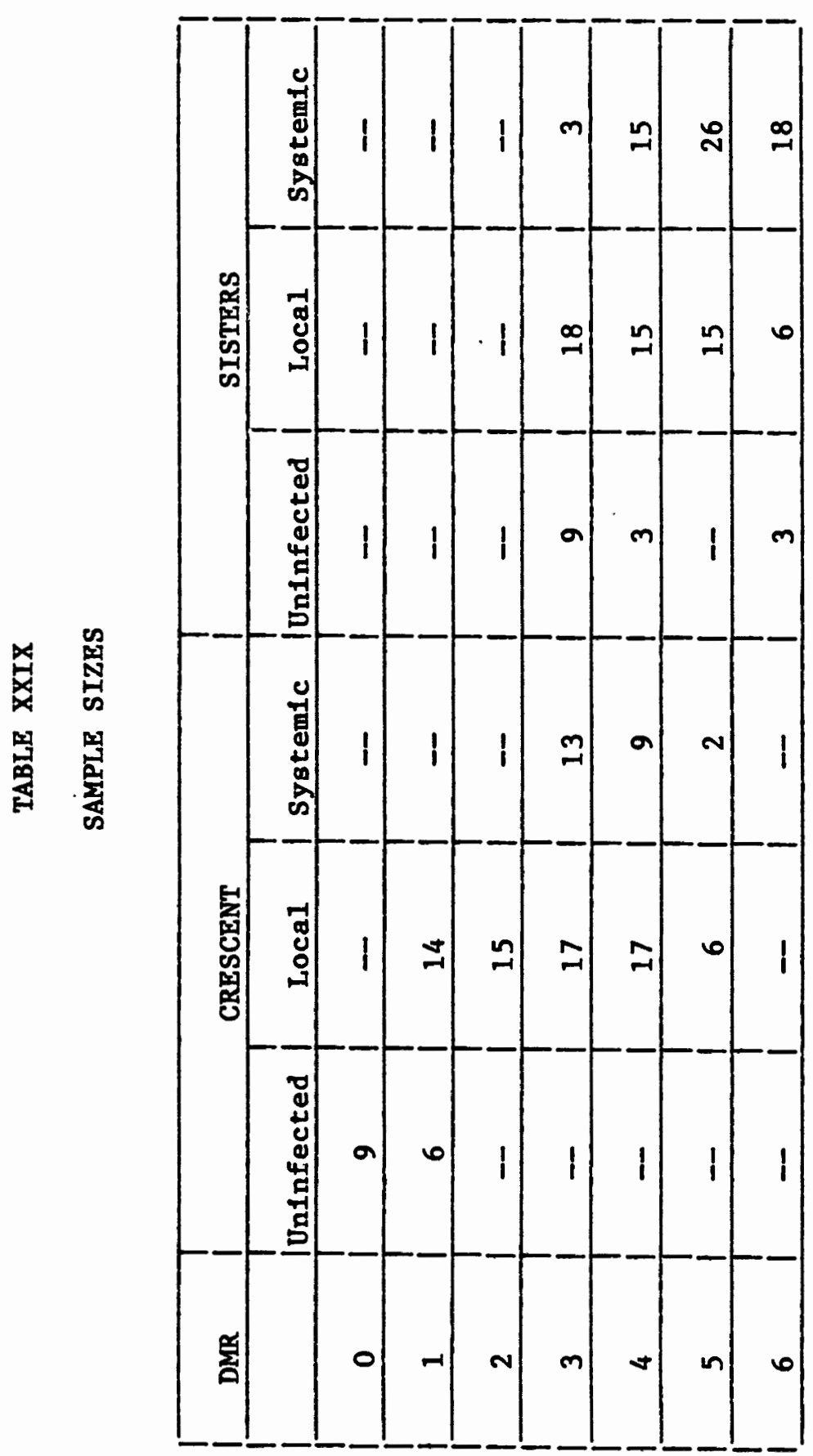

